\begin{tabular}{|c|c|}
\hline Title & Damage to Steel Buildings Observed after the 2011 Tohoku-Oki Earthquake \\
\hline Author(s) & Okazaki, T aichiro; Lignos, Dimitrios G.; Midorikawa, Mitsumasa; Ricles, James M.; Love, Jay \\
\hline Citation & $\begin{array}{l}\text { Earthquake spectra, 29, S219-S243 } \\
\text { https://doi.org/10.1193/1.4000124 }\end{array}$ \\
\hline Issue Date & $2013-03$ \\
\hline Doc URL & http:/hdl.handle.net/2115/54932 \\
\hline Rights & $\begin{array}{l}\text { Copyright } 2013 \text { Earthquake Engineering Research Institute. This article may be downloaded for personal use only. A ny } \\
\text { other use requires prior permi ssion of the Earthquake Engineering Research Institute. }\end{array}$ \\
\hline Type & article (author version) \\
\hline File Information & MS \#033112EQS119MR.pdf \\
\hline
\end{tabular}

Instructions for use 


\title{
Damage to Steel Buildings Observed After the 2011 Tohoku Earthquake
}

\author{
Taichiro Okazaki, ${ }^{\text {a) }}$ Dimitrios G. Lignos, ${ }^{\text {b) }}$ M.EERI, Mitsumasa \\ Midorikawa, ${ }^{c)}$ M.EERI, James M. Ricles, ${ }^{\text {d) }}$ M.EERI, and Jay Love, ${ }^{\text {e) }}$ M.EERI
}

A joint U.S.-Japan reconnaissance team examined the damage to steel building structures caused by the 2011 off the Pacific Coast of Tohoku Earthquake. In the city of Sendai, where the peak horizontal ground acceleration exceeded $1 \mathrm{~g}$, the majority of steel buildings performed well. Buildings that used older cladding systems for external finish sustained damage to their claddings even if their structural performance was excellent. Damage to a few braced frames offer insight into the seismic design of bracing connections. In areas attacked by violent tsunami, many steel buildings stood upright after the tsunami subsided, although these buildings lost much of their external and internal finishes along with their contents. These steel buildings did not provide safe shelter for tsunami evacuation when the building submerged under the tsunami wave. A number of buildings suffered foundation failure, which was likely caused by scouring or liquefaction or the combination of multiple effects.

\section{INTRODUCTION}

At around 14:46 on March 11, 2011, a magnitude $\left(\mathrm{M}_{\mathrm{w}}\right) 9.0$ earthquake occurred off the Sanriku coast of Japan. This event, officially named the 2011 off the Pacific Coast of Tohoku Earthquake and abbreviated as the 2011 Tohoku Earthquake, caused major disaster over an extensive area of Japan. Severe ground motion was recorded over the prefectures of Iwate, Miyagi, Fukushima, and Ibaraki. The majority of engineered building structures performed well under the severe motion. On the other hand, the ground motion caused disruption to the Tokyo metropolitan area, more than $300 \mathrm{~km}$ away from the epicenter, where high-rise buildings resonated to long-period ground motion and commuter rails were stopped for repair for up to a week. The main event was followed by more than 400 aftershocks including an

\footnotetext{
a) Hokkaido University, Kita 13, Nishi 8, Kita-ku, Sapporo, Hokkaido 060-8628, Japan

b) McGill University, 817 Sherbrooke West, Montreal, Quebec, H3A 2K6, Canada

${ }^{c}$ Hokkaido University, Kita 13, Nishi 8, Kita-ku, Sapporo, Hokkaido 060-8628, Japan

d) Lehigh University, 13 East Packer Avenue, Bethlehem, PA 18015-3176

e) Degenkolb Engineers, 300 Frank H. Ogawa Plaza, Oakland, California 94612
} 
$\mathrm{M}_{\mathrm{w}} 7.1$ event at 23:32 on April 7, 2011, and a number of remotely triggered earthquakes, such as an $M_{w} 6.7$ event in Nagano on March 12 and an $M_{w} 6.4$ event in Shizuoka on March 15. The main event produced a massive tsunami that washed the Pacific coast of the Japanese archipelago. As widely recognized, the most devastating aspect of the 2011 Tohoku Earthquake disaster is the extensive damage to port facilities and townships and the nearly 20,000 lives lost in the prefectures of Iwate, Miyagi, and Fukushima. The same tsunami caused the nuclear disaster in Fukushima whose aftermath shall impact the residents over generations. Destruction of factories by the earthquake and tsunami caused unexpected worldwide disruption to the supply chain, and thereby exposed the vulnerability of many industries.

While the lessons to be learned from the earthquake and tsunami disaster span many disciplines and specialties, this paper discusses the performance of steel building structures observed by a joint U.S.-Japan reconnaissance team. The areas visited by the team are shown in Figure 1. The coastal area of Natori and Sendai, and the Tohoku University campus were visited on June 3, 2011. Onagawa and Ishinomaki were visited on June 4. The Oroshinachi district of Sendai was visited on June 5. These sites were within the area exposed to the most severe ground motion from the March 11 event and to another severe ground motion from the April 7 aftershock. The coastal sites were exposed to both ground motion and tsunami. The remainder of this paper describes the observed damage in two separate categories: ground motion and tsunami effects.

\section{EARTHQUAKES AND TSUNAMI IN TOHOKU}

Tohoku is one of the most seismically active regions in Japan. Records indicate that the seabed off the coast of Sendai has been the epicenter of major earthquakes with a recurrence period of 30 to 40 years. The $\mathrm{M}_{\mathrm{w}}$ 7.7, 1978 Miyagi Earthquake claimed 27 lives and damaged thousands of buildings including a number of steel buildings. This earthquake was followed by a major update of the Japan Building Standard Law in 1981 that drastically modified the seismic design regulations. The most recent events in the region were the $M_{w} 7.2,2005$ Miyagi Earthquake and the $\mathrm{M}_{\mathrm{w}}$ 6.9, 2008 Iwate-Miyagi Nairiku Earthquake. Due to the very frequent exposure to earthquakes, the buildings in Sendai have been better prepared for earthquakes than any other region in Japan.

Meanwhile, due to the proximity to the Japan Trench, a subduction zone that produces 
large earthquakes, and the geography of the coastline (a "ria" coast) that accentuates tsunami violence, the Sanriku coast is prone to tsunami devastation. Thousands of lives were lost in the 1896 and 1933 Sanriku Earthquakes, and more than one hundred lives were lost due to the tsunami produced by the far distant 1960 Chilean Earthquake. However, industrial development of the ports, including the port of Ishinomaki that is discussed later in this paper, had not started until the 1960's. Today, the Sanriku coast is a rich fishing area that houses many fishing ports. Major port facilities, fish processing factories, refrigeration buildings, and distribution hubs have been constructed close to the shoreline, and many of those structures are constructed with structural steel. The 2011 Tohoku Earthquake produced the first major tsunami that attacked these industrialized ports.

The 2011 Tohoku Earthquake occurred near the Japan Trench and was significantly larger than previous earthquakes at this location. Therefore, this was an unusual earthquake even for this seismically active region and the first earthquake that produced severe damage due to both ground motion and tsunami in modern Tohoku.

\section{GROUND MOTION EFFECTS}

\section{General Observations}

Ground motion effects were examined in the city of Sendai. The reconnaissance team visited the Aobayama campus of Tohoku University and the Oroshimachi district (see Figure 1), based on earlier reports that structural and nonstructural damage was concentrated in these two locations. These are the same locations where concentrated damage was observed after the 1978 Miyagi Earthquake.

When the team visited the city, central Sendai appeared to have suffered very limited damage. Many hotels had reopened and the business district was operating nearly at the normal level. The only indication of a recent earthquake was the ongoing façade repair seen in every block. Motosaka (2012) describes that western Sendai, including the business district, is situated on bedrock, while the eastern part, including Oroshimachi and reaching the shoreline, is situated on alluvial deposits. Due to these geological conditions, the ground motion tends to be more severe in the eastern part of Sendai.

Figure 2 shows an enlarged view of Oroshimachi, an area slightly smaller than $4 \mathrm{~km}^{2}$ (slightly larger than $1 \mathrm{mi}^{2}{ }^{2}$ ). Historically, the east half of Oroshimachi had been cultivated as a field of rice paddies until the municipal zoning policy was changed in the early 1970's to 
promote industrial and commercial development in the area. Consequently, the majority of structures in east Oroshimachi were constructed in the early 1970's. The west side is populated mostly by residential buildings. As in most other regions in Japan, single-family residences are constructed with either timber or light-gauge steel, while condominium and apartment buildings are typically constructed with reinforced concrete (RC). The east side is populated by a mix of office buildings, stores, warehouses, delivery hubs, and factories. A large proportion of these structures, roughly half of the commercial buildings and the majority of factories and warehouses, were constructed with steel. Extensive damage to office buildings and warehouses was observed in this area after the 1978 Miyagi Earthquake.

Motosaka (2012) describes that the recorded motion from Oroshimachi was amplified over the motion from a bedrock station $4 \mathrm{~km}$ away, particularly in the period range below 1 second. The amplification was more substantial in the NS component than in the EW component. As indicated in Figure 2, two recording stations, station MYG013 of the National Institute for Earth Science and Disaster Prevention (NIED) K-NET array and station 23 of the Tohoku University-Disaster Control Research Center (DCRC), were placed in Oroshimachi. Figure 3 shows the ground acceleration history recorded from these stations. The duration of the strong motion exceeded two minutes. The records suggest that two separate strong motions arrived less than one minute apart. The MYG013 record shows extremely large PGA exceeding $1.5 \mathrm{~g}$ in the NS component. The team visited this station and observed evidence of soil liquefaction surrounding the equipment. Therefore, station MYG013 may have been affected by the local soil condition. Figure 4 shows the acceleration response spectra for the horizontal components of the DCRC record based on a damping ratio of $\xi=0.05$. Both components had large spectral accelerations in a period range between 0.5 and $0.8 \mathrm{~s}$, but were not particularly severe in the period range near $1 \mathrm{~s}$.

Within Oroshimachi, one collapsed and three severely damaged RC buildings were noted. Some of these RC buildings are shown in Figure 5 and their locations are indicated in Figure 2 as RC-Buildings A to C. A second collapsed RC building in east Oroshimachi is reported to have been demolished by early May. Limited damage was observed in the large number of single-family residences, old and new, in the area. A large proportion of these residences were constructed with light-gauge steel, which is the material of choice for mass-production construction companies, or timber. Studies of past earthquakes (Sakai et al. 2002) suggest that collapse of Japanese residential structures is caused by strong motion in the 1 to $2 \mathrm{~s}$ range. 
Therefore, the observed damage coincides with the response spectra shown in Figure 4 which suggest that the ground motion was damaging to low-rise RC structures with a fundamental vibration period of $0.2 \mathrm{~s}$ or shorter, but not particularly damaging to residential structures.

\section{Steel Buildings}

In Japan, steel structures have maintained a 35 to $40 \%$ share of the total constructed floor area since 1985 (JISF 2011). Excluding light-gauge steel residences, the majority of steel buildings use full moment-resisting frames (MRFs) with cold-formed, square-HSS columns (Nakashima et al. 2000). Unlike US construction, where the beam is field-welded to the column, typical Japanese construction uses beam stubs that are welded to the column in the shop. The middle portion of the beam is bolted to the beam stubs in the field. The HSS columns are diced into small segments to insert stiffener plates that act as continuity plates at the location of the beam flanges. The stiffeners are connected to the column by completejoint penetration groove welds. Examples of the framing systems and beam-to-column connections can be viewed in some of the photos shown in the section on tsunami effects. On the other hand, since 1981, the Japanese Building Standard Law discourages the use of concentrically braced frames (CBFs). Therefore, while CBFs were fairly common prior to 1981, today, the application of CBFs may be limited to gymnasiums, factories, warehouses, parking garages, and seismic upgrading of RC structures. While the use of "buckling" braces have faded, advanced structural systems placing energy dissipating devices (e.g., bucklingrestrained braces, viscous dampers, hydraulic dampers, viscoelastic dampers) for the braces have gained popularity, particularly for buildings taller than $60 \mathrm{~m}$.

In Oroshimachi, where one RC building collapsed and three more were severely damaged, there was no report of a severely damaged steel building. A small number of steel buildings were being demolished for unknown reasons in early May, prior to the joint reconnaissance visit. In the example shown in Figure 6, signs of structural damage were limited to mild panel zone yielding in W-shape columns. Many steel buildings were tagged "unsafe" by safety evaluation, but the reason was primarily nonstructural rather than structural damage. Figure 7 shows examples of steel buildings whose external claddings suffered severe damage. The exposed steel framing in these examples showed no sign of structural damage. Consequently, the authors believe that no substantial damage occurred to steel buildings in Oroshimachi.

Meanwhile, notable damage was observed in some CBF structures. Figure 8 shows a steel 
office building with an 8-span CBF in the NS-direction and a single-span MRF in the EWdirection. The external wall finish was completely removed from the north and west sides (see Figures 8(a) and (b), respectively), while no damage was observed on the south and east walls. According to the owner, the west wall fell entirely and the north wall was severely cracked after the March 11 event. The north and west walls were made of lath and mortar, but the south and east walls had been replaced with steel siding boards after the original wall was damaged by the 2008 Iwate-Miyagi Nairiku Earthquake. Clear evidence of soil deformation was noted along the west end of the building. The NS-frame used small beams that were simply connected to the column web, and hence depended solely on the braces for lateralload resistance. Figures 8(b) and (c) show X-braces comprising double-angle members. One brace ran continuously through the middle gusset plate, while the other brace comprised two separate double-angle segments bolted to the middle gusset plate and separated by $150 \mathrm{~mm}$. Figure 8(c) shows large bending deformation of the middle gusset plate, which produced misalignment of the discontinuous brace and severe twisting of the continuous brace. Figure 8(d) shows fracture of an end gusset plate and at the reduced section of a continuous brace. There was no evidence that the braces had yielded in tension. It is suspected that the gusset plate fracture was a result of torsional deformation imposed on the gusset plate and eccentricity in the gusset plate geometry. The lack of consideration for post-elastic response suggests that this building was designed prior to 1981 .

Figure 9 shows a photo and the floor plan of a parking garage that experienced severe damage to its bracing connections. The garage is a two-story, chevron CBF with 7 spans in the NS-direction and 9 spans in the EW-direction. Because the beams were simply connected to the columns, this structure relied solely on the braces for lateral-load resistance. However, as shown in Figure 9(a), braces in both stories failed by fracture in the upper-end bracing connection. Figure 9(b) indicates the location of bracing connection failure in the first story of this parking garage.

The pattern of failure was common at all locations. Figure 10 shows some examples. Figure 10(a) shows a beam sagging in the middle after a plastic hinge formed due to force unbalance between the tension and compression braces. Figures 10(b) and (c) show a closer view of fractured gusset plates. The gusset plates on the upper end, which were unsupported along the edges, were clearly more flexible than the gusset plates on the lower end. The difference in out-of-plane flexibility must have caused the fracture to occur only on the 
upper-end gusset plate. The common failure pattern indicated that the gusset plate fracture was caused by (i) out-of-plane eccentricity in the bolted connection; (ii) stress concentration between the tube-to-gusset weld and nearest bolt line, and (iii) lack of consideration for an out-of-plane fold line. It is suspected that bending deformation caused by eccentricity was confined in a very small segment of the gusset plate. The location of stress concentration coincided with the region of confined bending. This structure was not detailed for ductile behavior. Because the gusset plates $(260 \times 12 \mathrm{~mm})$ had nearly the same cross-sectional area as the braces (Round HSS $165 \times 6 \mathrm{~mm}$ ), fracture in tension might not be predicted by design calculations.

Figure 10(d) shows a column base where two braces frame in from orthogonal framing directions. The extensive cracking in the asphalt indicate that substantial uplift force acted at this column base when the orthogonal braces simultaneously developed tension.

\section{Response History Analysis of the Parking Garage}

Figure 9(b) indicates the location of gusset plate fracture in the parking garage. Out of the 32 braces in the EW direction, 27 fractured in the upper-end gusset plate and 5 were severely bent in the upper-end gusset plate. Out of the 30 braces in the NS direction, 18 were severely bent and 12 appeared undamaged. The directionality in damage was examined by a threedimensional linear-elastic analysis. The parking garage was modeled with elastic beam elements for the beams and columns, truss elements for the braces, and rigid diaphragms to represent the reinforced concrete slabs. The gusset plates were modeled by rigid offsets. The fundamental vibration periods in the EW- and NS-directions were computed as $0.26 \mathrm{~s}$ and $0.21 \mathrm{~s}$, respectively. Figure 4 suggests that the NS- and EW-components had very similar spectral acceleration amplitudes in the period range of 0.1 to $0.5 \mathrm{~s}$ but that the NS component is more prominent at longer periods. Torsional response was negligible.

Response history analysis was performed with this model using all three components of the ground motion recorded at DCRC No. 23. Figure 11 shows the axial force histories of the two perimeter braces indicated in Figure 9(a), with the dotted lines indicating the nominal tensile and compressive strength of the brace. The axial force demand exceeded the capacity 7 times as many times in the EW brace and than in the NS brace. Therefore, although the acceleration response spectra suggest that the structure was subjected to similar demands in both directions, the analysis results suggest that the EW braces were subjected to larger force 
demands than the NS-braces, and larger number of high force cycles, which agrees with the observations that damage in the EW braces was much more substantial. This is attributed to the fact that the bay widths in the EW direction are smaller than in the NS direction.

\section{SRC Buildings}

Steel-encased Reinforced Concrete (SRC) is a structural system unique to Japan that comprises concrete members with encased steel sections and reinforcement. Between 1970 and 2000, SRC accounted for 10\% of the total constructed floor area in Japan (JISF 2011). SRC is a highly regarded structural system that combines the merits of steel and reinforced concrete. However, due to its cost premium, SRC has been losing favor since the mid 2000's.

SRC-Building A, shown in Figure 12, is an older SRC structure located in the Aobayama campus of Tohoku University (see Figure 1) and constructed in 1969. The structure is vertically irregular in mass, stiffness, and strength, since it consists of two podium levels and six tower stories above. This building was damaged by the 1978 Miyagi earthquake and had since been seismically strengthened in two phases (Motosaka et al. 2004). As reported by Motosaka (2012), all corner columns were severely damaged at the transition floor from the tower to the podium level. No evidence of damage was noted in the steel braces implemented in the third story for seismic upgrade. As shown in Figure 12(b), when the team visited the building, the damaged columns had been temporarily repaired with concrete encasement and dywidag bars to provide for safe access. This building is planned to be demolished. Motosaka (2012) noted that, at this site, the ground motion was amplified over the bedrock motion at a period of $1 \mathrm{sec}$, which happened to coincide with the vibration period of SRC-Building A.

SRC-Building B, shown in Figure 13, is a condominium building constructed in 1976 in a river delta (see Figure 1) and designed with a pile foundation. Motosaka (2012) measured the residual roof drift ratio of this building after the main event and April 7 aftershock to be 1/45, and attribute the cause to be damage in the piles resulting from soil liquefaction. In fact, evidence of liquefaction surrounding the building was clearly observed. While little damage was noted in the superstructure, cracking in the nonstructural walls, an example of which is shown in Figure 13(b), was widespread. This building experienced very similar damage from the 1978 Miyagi Earthquake. Since then, the building had been resided after the piles were repaired and nonstructural damage was repaired. By the time the team visited, the owners had decided to demolish the building. 
SRC-Building C, shown in Figure 14, is a residence complex in Oroshimachi (see Figure 2) composed of three, 11-story SRC buildings. The cracks in nonstructural walls, such as those shown in Figure 14(a), were observed along the entire height of the three buildings. Figures 14(b) and (c) show one corner of the complex where a 10-cm gap was left between adjoining buildings. Spalling of concrete at this location suggested that the two buildings pounded against each other. Despite the cosmetic damage, the SRC buildings seemed to have suffered minimal structural damage. At the time of investigation, many residents had returned to occupy the building.

\section{Damage to External Non-Structural Elements}

In Japan, steel industrial buildings constructed before the 1970's used timber lath or corrugated metal coated with mortar, or otherwise exposed corrugated metal, for their external finish. Currently, Autoclaved Lightweight Concrete (ALC, known as Autoclaved Aerated Concrete or AAC in the US) panels is the material of choice for non-load bearing, external cladding for steel structures. Prefabricated, standardized ALC panels are used for various steel buildings including residences constructed of light-gauge steel, office buildings, warehouses, and industrial buildings.

Widespread damage to all types of external finishes was observed in Oroshimachi. Figure 15 shows damage to older structures where blocks of mortar fell over an extended area. Figure 7(a) shows a warehouse building where ALC panels fell from the second story. Figure 7(b) shows a three-story office building where ALC panels fell off a steel moment frame over one quarter of the perimeter, and where the remaining ALC panels show extensive damage along the panel boundaries. These are few examples of the widespread damage to ALC panels in office buildings, warehouses, and factory buildings. These buildings were two- to three-story high, and believed to be at least ten years old. Figure 16 illustrates the typical method of ALC panel installation that was used until ten years ago. This method, which rigidly connects the ALC panels to each other and to the structural frame, led to extensive damage to ALC panels during the 1995 Kobe earthquake. Over the last decade, an improved ALC panel installation method has been in use, which accommodates drifts up to $0.02 \mathrm{rad}$ (Okazaki et al. 2007). All ALC panel damage observed by the investigation team, including those shown in Figure 7, used the older method shown in Figure 16. As noted earlier, despite the severe damage to ALC panels, few evidence of structural damage was found. A possible exception was the braced frame building shown in Figure 8. Therefore, the observed damage 
was likely caused by the inability of the ALC panels to accommodate story drift of the structural frame, even though the story drift was rather limited.

\section{TSUNAMI EFFECTS}

\section{General Observations}

Tsunami effects of the 2011 Tohoku Earthquake were examined at four coastal locations, the Yuriage District of Natori, Sendai Port, Ishinomaki, and Onagawa (see Figure 1). Yuriage was a densely populated residential area. Sendai port is the largest transportation hub in North-East Japan. Ishinomaki housed, until the disaster, one of the largest fishing ports in Japan. Onagawa is a fishing port where the tsunami reached an extreme height. The differences in tsunami damage due to location and composition of structures are discussed in this section.

The tsunami produced by the 2011 Tohoku Earthquake caused devastating damage along the Pacific Coast of Japan. Figure 17 illustrates the tsunami inundation height measured along the coast where nearly 20,000 lives were lost. As indicated in this figure, the fault, reported to be 400-km long, lay parallel and about $200 \mathrm{~km}$ from the coast. Although many harbors and townships were within similar proximity to the fault, the tsunami height varied substantially depending on the geographic condition. The tsunami tended to be lower at harbors protected by intertwined bays and at harbors that did not directly face the Pacific Ocean. The tsunami reached extreme height and violence at harbors constructed at the end of a narrowing bay. The Port and Airport Research Institute (2011) report the peak tsunami inundation height to be $12 \mathrm{~m}$ at Sendai airport, which is near Yuriage, $8 \mathrm{~m}$ in Sendai Port, 5 $\mathrm{m}$ in Ishinomaki, and $15 \mathrm{~m}$ in Onagawa.

The Tohoku region was well aware of the tsunami risks. In the populated areas, taller buildings were strategically placed for vertical evacuation, similar to the policy suggested by FEMA (2008). These evacuation buildings were constructed with RC or SRC, and were designed to withstand the expected tsunami loads. However, the tsunami height and violence that followed the 2011 Tohoku Earthquake far exceeded what the region had prepared for. While the evacuation buildings saved many lives, many other lives were lost in evacuation buildings that submerged under the tsunami. Massive tsunami protection seawalls were destroyed at many locations. The tsunami rose and receded multiple times and turned the port and township into massive debris. 


\section{Onagawa}

At Onagawa, a fishing port located at the end of a narrowing bay, the tsunami reached an extreme inundation height of 15 meters. Watermarks indicated that the run-up height of the water was substantially higher. After the tsunami subsided, the entire town was destroyed. The ruins indicated that a large proportion of the buildings in downtown Onagawa were constructed with steel. Most of the large fish processing factories and refrigeration buildings in the bay opposite downtown area were constructed with steel. The steel buildings in downtown were severely destroyed as seen in Figures 18(a) and (b). In the same area, surprisingly, a number of buildings stood upright. For example, the building shown in Figure 18(c) lost much of its exterior and interior finish and its contents. The exposed structural framing shown in Figure 18(d) shows no sign of structural damage. Although not shown here, there was some differential settlement in the soil surrounding this building.

Figure 19 shows a three-story office building that stood in the middle of downtown Onagawa and $100 \mathrm{~m}$ from the shore. This building had traveled $15 \mathrm{~m}$ inland from its original location, and lied overturned. Figure 19(a) shows the roof on the right end and the footing on the left end. Minimal structural damage was observed in the 1-bay by 3-bay, steel MRF superstructure partly visible in Figure 19(b). Figure 19(c) shows the foundation, viewing the building from the shore side. The footing foundation suffered minimal damage. However, as Figure 19(d) shows, some of the piles were pulled out with damage concentrated at the connection to the cap. This building had the external ALC panels intact. Therefore, unlike other steel buildings in this area, substantial buoyancy force must have acted when this building submerged in tsunami to the roof (BRI 2011; 2012). The authors suspect that the piles, damaged by ground motion and soil liquefaction, and further loosened by scouring, were pulled out by the tension produced by overturning moment and buoyancy.

Figure 20 shows a two-story steel structure, located $100 \mathrm{~m}$ from the shoreline, and which entirely lost its exterior and interior finishes. The 1-bay by 3-bay structure employs X-braces in two of the three bays perpendicular to the shoreline, and an MRF in the other direction. A second-story collapse mechanism formed in the direction perpendicular to the shoreline, presumably after all X-braces in the second story failed. Based on this failure mechanism, Hayashi and Tamura (2012) estimated that the tsunami force applied to the shore side façade of this structure to be $24 \mathrm{kN} / \mathrm{m}^{2}$ or greater.

Figure 21 shows a small three-story building that stood inclined due to foundation 
settlement. Figure 21(a) shows the extreme inclination. The external and internal finishes and the roof were completely washed away. As shown in Figure 21(b), one corner of the building sunk into a pocket in the ground that was presumably produced by scouring.

\section{Ishinomaki}

Although the reported peak tsunami height of $5 \mathrm{~m}$ may appear unimpressive compared to the $15 \mathrm{~m}$ in Onagawa, the damage at Ishinomaki was substantial. Ishinomaki lost more lives than any other location. Examples of damaged steel buildings near the main port and fishing port are shown in Figure 22. Figure 22(a) shows a port facility adjacent to the shoreline with structural and nonstructural damage. Figure 22(b) shows one of many collapsed buildings in the fishing port. Meanwhile, Figure 22(c) shows a three-story office building with substantial nonstructural damage in the first story, but minimal structural damage. Figure 22(d) is an interior view of the first story, which was filled with debris, but which showed no indication of structural damage. Figure 22(e) shows another example of a structure with substantial nonstructural damage in the first story but minimal structural damage. Figure 22(f) shows the

first story of the same factory building, where the external and internal finish was lost but no sign of structural damage was observed.

Evidence of debris impact was noted in some structures including the two large facilities shown in Figure 23. Both facilities are located in the fishing port of Ishinomaki, within $200 \mathrm{~m}$ from the shoreline. Figure 23(a) shows a refrigeration facility that lost its exterior finish on the side facing the shore. The fourth column from the left end is kinked in the middle and twisted. Figure 23(b) shows a close-up view of the kink, while Figure 23(c) shows the base of this column. The localized flange deformation in the kink and fracture of all four anchor bolts at the base indicates that the damage is the consequence of a large concentrated force. Figure 23(d) shows another facility that stored Styrofoam for fish packaging. Aerial photos taken within days from the earthquake show large debris piled up on the shore side of each of these two facilities. Therefore, the localized damage shown in Figure 23 was likely caused by the impact of adjacent structures.

Figure 24 shows a two story school gymnasium near the fishing port and $250 \mathrm{~m}$ from the shoreline. The building was separated from the shore by a pine tree forest that remained after the tsunami subsided. As in typical elementary to high school gymnasiums, this gymnasium was constructed as a Gable moment frame in one direction and a braced frame in the other 
direction. The exterior wall was lost at the first floor, and the floor was damaged (see Figure 24(b)). Figure 24(c) shows the bottom side of the damaged floor where the deformed floor panels lifted the stone footings off the soil. While minimal damage was observed in the vertical frame, as shown in Figure 24(d), many of the roof bracing had failed by fracture of the bolts connecting the turn-buckle braces to gusset plates. Because it is unlikely that tsunami could produce substantial forces in the roof, and because this is a typical damage observed in school gymnasiums after earthquakes, the authors suspect that the brace failure was caused by ground motion rather than tsunami.

\section{Yuriage}

The Yuriage District of Natori is a residential area near Sendai that was completely destroyed by the tsunami. The area was densely populated with timber and light-gauge steel residences, low-rise RC apartments, schools, and a small number of factories and office buildings constructed with steel. Figure 25 shows the remains of residences. Figure 25(a) shows the concrete foundation of a residence and evidence of scouring surrounding the foundation. Figure 25(b) is an example of a light-gauge steel residence that stood upright but suffered extensive damage to its exterior and contents. Figure 25(c) shows a three-story residence constructed with $\mathrm{RC}$ in the first story and timber in the upper stories. This example suggests that the elevation added by the RC portion helped the structure survive the tsunami.

Figure 26 shows a university boat club facility located within $50 \mathrm{~m}$ from the shore. The structure is a 3 by 3-bay, two-story MRF with galvanized steel members. Although no structural damage was noted, the structure was inclined by $0.01 \mathrm{rad}$. The exterior and interior claddings were ruined up to the second floor, and the ALC floor panels were severely damaged.

\section{Sendai Port}

Figure 27 shows a distribution center located one block away from the shoreline of Sendai Port. This is one of many facilities in the port that were destroyed by tsunami. The damage to external cladding in the office building shown in Figure 27(b) indicates that the first story level was washed by tsunami. A report by BRI (2011) concludes that a vehicle carried by tsunami hit the freight dock and caught fire, and independently, another fire started from within the large-bay area. Figure 27(c) shows a close-up view of the burned roof. 


\section{CONCLUDING REMARKS}

This paper summarizes the observations made by a joint U.S.-Japan reconnaissance team whose mission was to examine the damage to steel structures after the 2011 Tohoku Earthquake. Reconnaissance was conducted in the areas surrounding Sendai. Ground motion effects were studied in the Tohoku University campus and Oroshimachi District of Sendai. Tsunami effects were studied in Natori, Sendai, Onagawa, and Ishinomaki. The following are the observations on ground motion effects:

(1) Records indicate that the ground motion in Sendai had high PGA and very long duration exceeding two minutes. However, the ground motion had its principal period between 0.5 and $0.8 \mathrm{sec}$, and was not particularly strong in the 1 to 2 -sec period range that tends to produce the most destructive effects on steel structures. Available information and the reconnaissance findings indicate that steel structures performed well under this ground motion.

(2) Damage was observed in CBF structures including an old office building and a parking garage. These structures were not adequately detailed for ductile behavior. Extensive fracture in the bracing connections of the parking garage demonstrated the poor performance of bracing connections with eccentric geometry. Response history analysis of the parking garage demonstrated that the steel braces in the EW direction were subjected to larger forces than the braces in the NS direction. This agrees with field observations that damage in the EW direction was much more substantial.

(3) Damage to a few SRC buildings were caused by specific reasons. An SRC university building was constructed at a site where the ground motion was amplified right at its characteristic vibration frequency. An SRC condominium building was tilted after soil liquefaction led to damage in the pile foundation. Another SRC condominium building was damaged by pounding against each other.

(4) Damage to external finishes constructed from ALC panels was widespread. This was not a surprise because Japanese engineers have been aware that the older installation method that rigidly connects the ALC panels to the steel framing system leads to the observed failure pattern. A new method has been in use over the last decade to assure that the ALC panels accommodate story drifts up to $0.02 \mathrm{rad}$. Therefore, damage to ALC claddings is expected to become less frequent in future earthquakes. 
The following are the observations on tsunami effects:

(5) Prior to this earthquake, the engineering community had little knowledge of how steel structures may perform under extreme tsunami. A large number and a large variety of steel structures were attacked by the massive tsunami.

(6) In the most extreme cases, steel buildings were displaced from their original location and completely destroyed. In other cases, failure of connections and members caused the building to tilt or collapse. The strength of the column base seemed to play a key role in collapse prevention against tsunami. In structures whose claddings were completely washed away by the tsunami, structural damage was limited. It is suspected that the external claddings in these structures were easily damaged by tsunami and the early loss of claddings, although unintended, alleviated the immense lateral load that the tsunami pressure otherwise would have delivered.

(7) Many steel buildings stood upright after the tsunami subsided. However, without a single exception, steel buildings suffered extensive damage to their external and internal finishes along with their contents. Therefore, steel buildings designed according to the current Japanese standards may withstand large tsunami forces but they are not likely to provide safe shelter for tsunami evacuation when the building submerges under tsunami wave.

(8) The Tohoku coast experienced a multitude of destructive effects: severe ground motion, liquefaction, foundation scour, large lateral load produced by tsunami pressure, debris delivered by tsunami, and fire.

\section{ACKNOWLEDGMENTS}

The participation of the US and Canadian authors was supported by National Science Foundation Grant No. CMS-1142058 through the Earthquake Engineering Research Institute. The authors sincerely thank Professor Masato Motosaka and his colleagues at Tohoku University for their generous assistance that made the study possible. The findings and conclusions described in this paper are those of the authors and do not necessarily reflect the views of the organizations and individuals described herein.

\section{REFERENCES}

Architectural Institute of Japan (AIJ), 2011. Preliminary Reconnaissance Report of the 2011 Tohoku- 
Chiho Taiheiyo-Oki Earthquake, Maruzen, Tokyo, Japan (in Japanese).

Building Research Institute (BRI), 2011. Quick Report of the Field Survey and Research on "The 2011 off the Pacific coast of Tohoku Earthquake (the Great East Japan Earthquake), Technical Note of NILIM No. 636, BRI Research Paper No. 132, <http://www.kenken.go.jp/japanese/ contents/topics/20110311/031 1quickreport.html> (April 1, 2012, in Japanese).

Building Research Institute (BRI), 2012. Report on Field Surveys and Subsequent Investigations of Building Damage Following the 2011 off the Pacific coast of Tohoku Earthquake, Technical Note of NILIM No. 647, BRI Research Paper No. 136 (in Japanese).

Federal Emergency Management Agency (FEMA), 2008. Guidelines for Design of Structures for Vertical Evacuation from Tsunamis, FEMA P646, prepared by the Applied Technology Council for FEMA, Washington, DC.

Hayashi, K. and Tamura, S., 2012. Tsunami load acting on a small building observed in the 2011 off the pacific Coast of Tohoku Earthquake, Journal of Structural Engineering, Architectural Institute of Japan, 58B, pp. 117-123 (in Japanese).

Japan Iron and Steel Federation (JISF), 2011. Statistics of steel buildings, <http://www.jisf.or.jp/ business/tech/build/index.html> (March 30, 2012).

Motosaka, M., Sato, T., and Yamamoto, Y., 2004, The Amplitude Dependent Dynamic Characteristics of an Existing Building Before and After Seismic Retrofit, Proceedings, $13^{\text {th }}$ World Conference on Earthquake Engineering (13WCEE), Vancouver, B.C., Canada, August 1-6, Paper No. 1023.

Motosaka, M., 2012. Lessons of the 2012 Great East Japan earthquake focused on characteristics of ground motions and building damage, International Symposium on Engineering Lessons Learned from the 2011 Great East Japan Earthquake, March 1-4, 2012, Tokyo, Japan, pp. 166-185.

Nakashima, M., Roeder, C.W., and Maruoka, Y., 2000. Steel moment frames for earthquakes in United States and Japan, Journal of Structural Engineering, American Society of Civil Engineers 126(8), pp. 861-868.

Okazaki, T., Nakashima, M., Suita, K., and Matsumiya, T., 2007. Interaction between cladding and structural frame observed in a full-scale steel building test, Earthquake Engineering and Structural Dynamics 36, pp. 35-53.

Port and Airport Research Institute, 2011. Damage Assessment of Ports in Tohoku Region (Preliminary field survey report). Attachment 2: Reconnaissance results of respective ports, < http://www.pari.go.jp/files/items/3463/File/p20110323-3.pdf> (March 23, 2011).

Sakai, Y., Koketsu, K., and Kanno, T., 2002. Proposal of the destructive power index of strong ground motion for prediction of building damage ratio. Journal of Structural and Construction 
Engineering, Architectural Institute of Japan, 555, pp. 85-91 (in Japanese).

The 2011 Tohoku Earthquake Tsunami Joint Survey Group, 2011. The 2011 off the Pacific Coast of Tohoku Earthquake Tsunami Information, <http://www.coastal.jp/tsunami2011/> (May 20, 2011). 


\section{List of Figures}

Figure 1. Reconnaissance area (Image produced using http://maps.google.co.jp).

Figure 2. Key locations in Oroshimachi District (Image produced using http://maps.google.co.jp).

Figure 3. Ground motion records from Oroshimachi

Figure 4. Acceleration response spectra for DCRC No. 23

Figure 5. Severely damaged RC-Buildings: (a) A; (b) B; and (c) C.

Figure 6. (a) Steel building in Oroshimachi under demolition; and (b) sign of panel zone yielding.

Figure 7. Steel structures damaged in the exterior: (a) Warehouse A; and (b) S-Building A.

Figure 8. Damaged CBF structure (S-Building B): (a) North side exterior; (b) West side exterior; (c) bending of middle gusset plate in an X-brace; and (d) fractured gusset plate.

Figure 9. Parking Garage A: (a) photo; and (b) floor plan with indication of gusset plate fracture location in the first story.

Figure 10. Damage to Parking Garage A: (a) permanent deformation in the beam due to brace force unbalance; (b) fractured gusset plates; (c) closer view of a fractured gusset plate; and (d) cracking of asphalt covering a column base.

Figure 11. Axial force history for (a) NS-brace; and (b) EW-brace.

Figure 12. SRC-Building A: (a) Overall view; and (b) repaired corner column.

Figure 13. SRC-Building B: (a) Overall view; and (b) cracking in nonstructural walls.

Figure 14. SRC-Building C: (a) Cracking in nonstructural wall; (b) cracking in hallway slab; and (c) hallway framed by two buildings. 
Figure 15. External damage: (a) penthouse of a single-story factory; (b) two-story residence; and (c) factory with lath-and-mortar over corrugated metal cladding.

Figure 16. Older installation method for ALC panel claddings

Figure 17. Tsunami inundation height (Image produced from the 2011 Tohoku Earthquake Tsunami Joint Survey Group (2011)).

Figure 18. Steel buildings in Onagawa: (a) a building (1 by 6-bay, 2-story MRF/MRF) with evidence of debris impact; (b) a building (details unknown) deformed beyond recognition; (c) a building (2 by 3-bay, 3-story MRF/MRF) standing upright; and (d) interior of building shown in c.

Figure 19. Overturned steel building (1 by 3-bay, 3-story MRF/MRF) in Onagawa: (a) side view; (b) side view of opposite side; (c) exposed foundation; and (d) a pulled out foundation pile.

Figure 20. Deformed steel building (1 by 3-bay, 2story, MRF/CBF) in Onagawa: (a) side view showing the story drift of the second story; and (b) fractured X-brace and plastic hinging at the base of the 2-story W-columns.

Figure 21. Steel building (1 by 3-bay, 3-story, MRF/CBF) with foundation damage caused by scouring: (a) view of extreme inclination; and (b) scoured foundation.

Figure 22. Damaged steel buildings in Ishinomaki: (a) port facility (two identical structures, 7 by 1bay, single-story, MRF/Gable frame); (b) collapsed building (2-story, further details unknown); (c) office building (3 by 2-bay, 3-story, MRF/MRF) with nonstructural damage in the first story; (d) inside the office building; (e) factory ( 8 by 1-bay, 2-story, MRF/MRF); and (f) inside the factory. The port facility in (a) is located in the main port, while the three buildings in (b) through (f) are located in the fishing port.

Figure 23. Evidence of debris impact in Ishinomaki: (a) front view of refrigeration facility (6 by 3- 
bay, single-story, $\mathrm{CBF} / \mathrm{CBF}$ ); (b) close-up view of the kink in the fourth column; (c) anchor bolt fracture in base of the impacted column; (d) front view of storage facility (6 by 1-bay, single-story, $\mathrm{CBF} / \mathrm{CBF}$ ); and (e) anchor bolt elongation at the base of the impacted column.

Figure 24. School gymnasium (9 by 1-bay, single-story, CBF/Gable frame) near Ishinomaki fishing port: (a) view from North-West; (b) South side facing the shore (c) stone footing no longer supporting the floor; and (d) fractured turn-buckle roof braces.

Figure 25. Damage to residences in Natori: (a) foundation of a timber residence; (b) light-gauge steel residence; (c) timber residence over first story with RC.

Figure 26. Boat Club (3 by 3-bay, 2-story, MRF/MRF) in Natori: (a) exterior view; and (b) damaged floor and ceiling.

Figure 27. Distribution center and office in Sendai Port: (a) View of entire facility; (b) office portion; and (c) burned roof. 
Fig.1

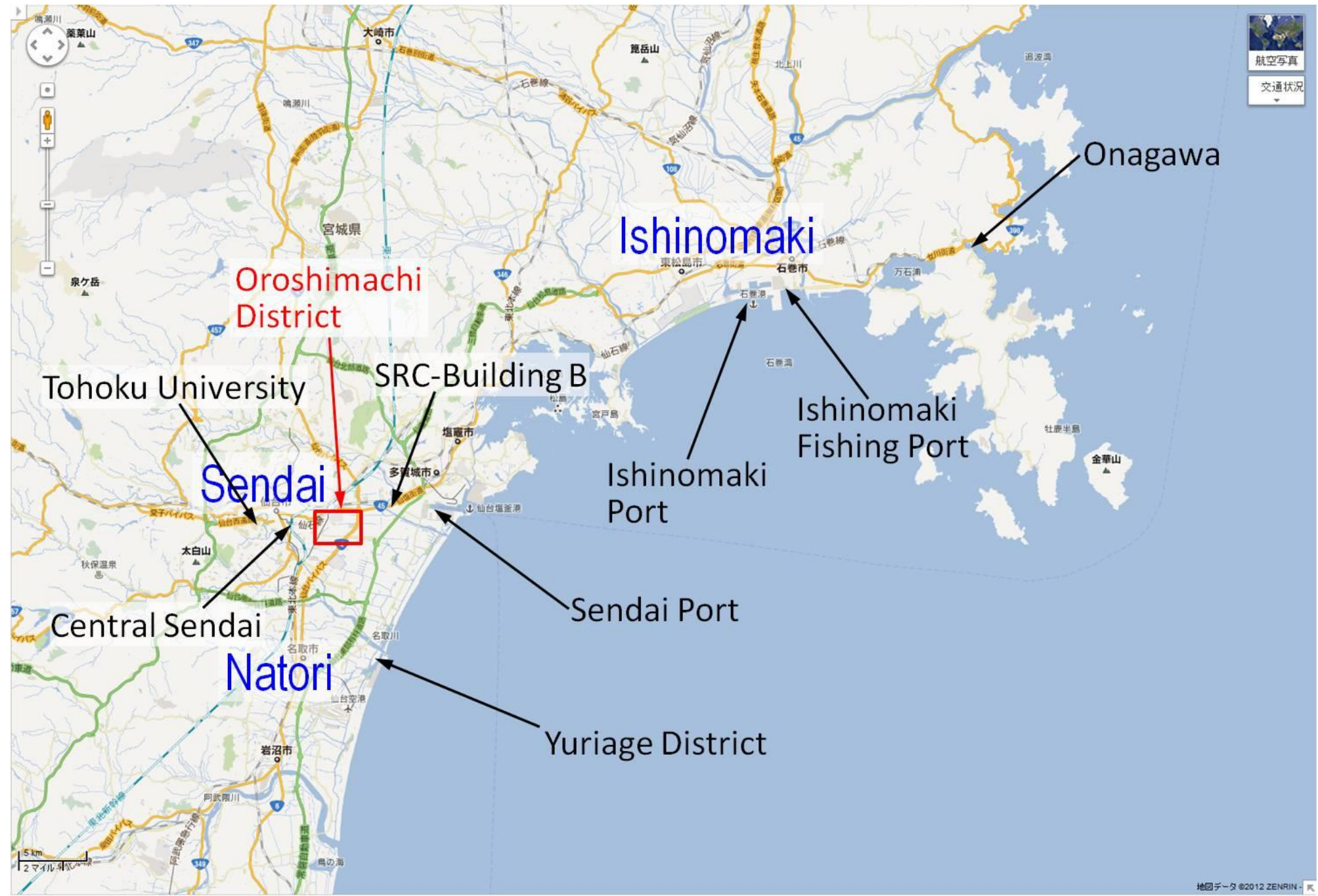


Fig. 2

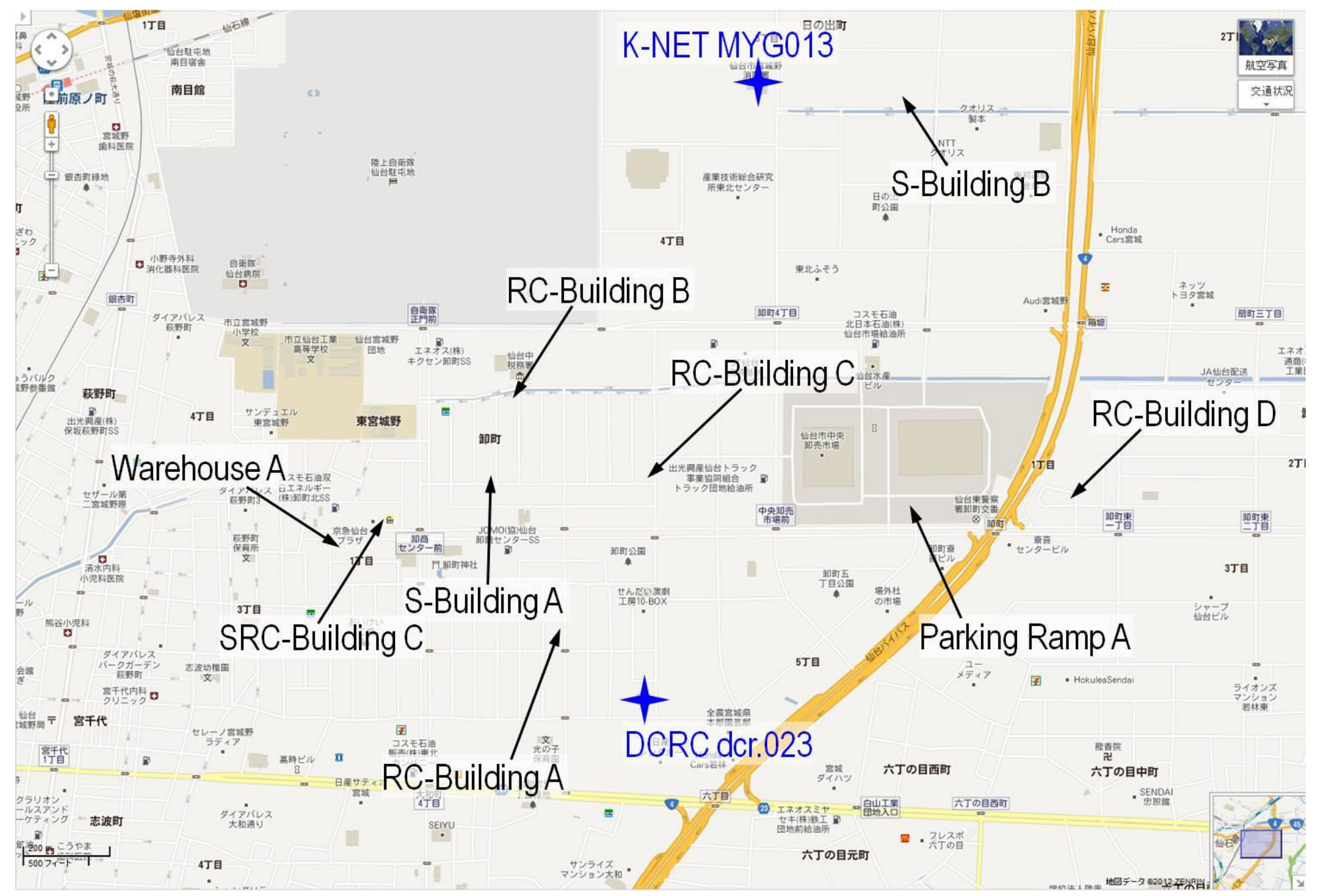


Fig. 3

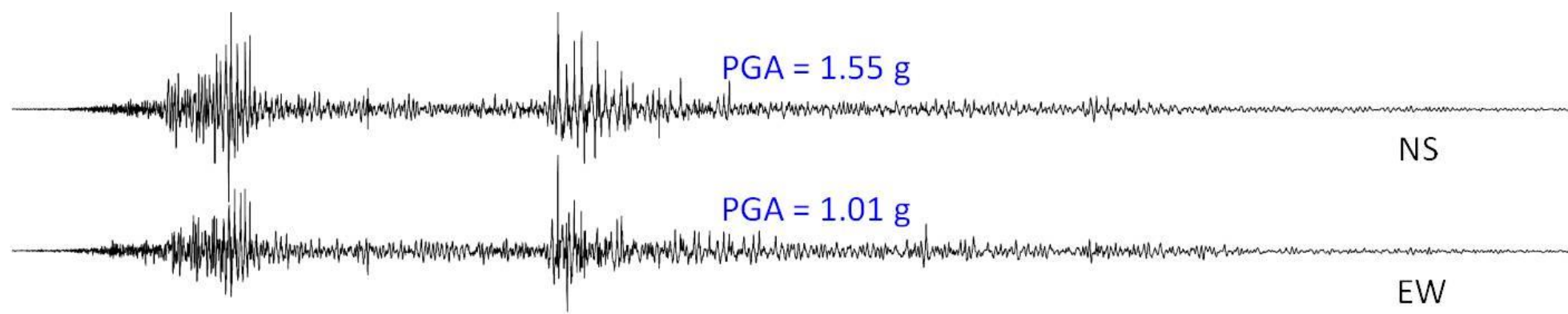

$P G A=0.31 \mathrm{~g}$

K-NET MYG013

UD

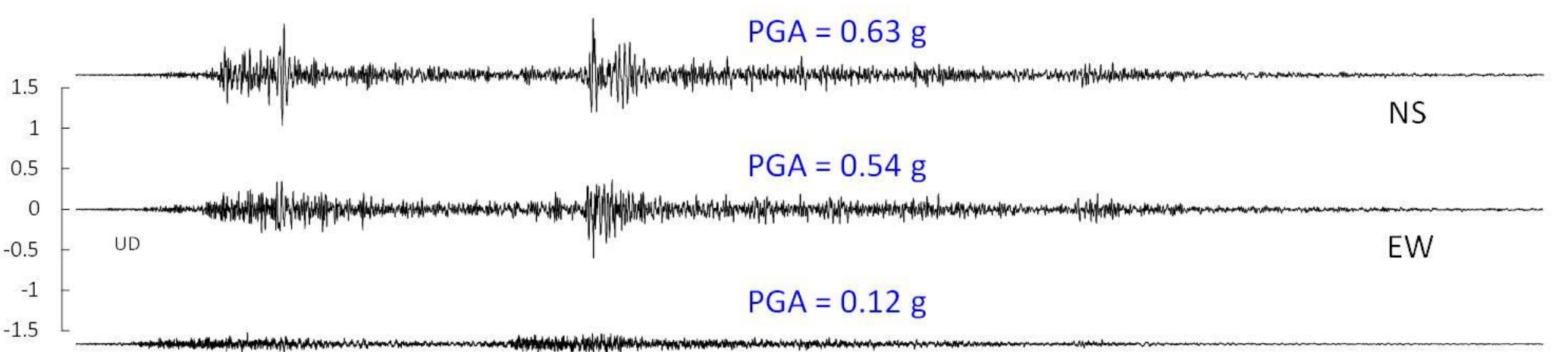

DCRC No. 23

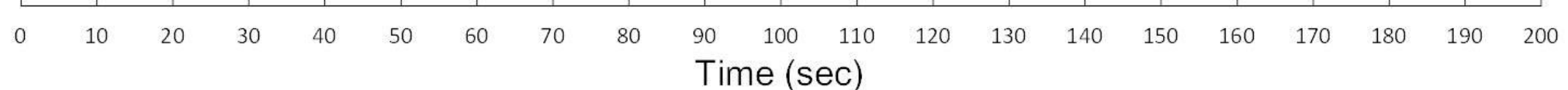

Time (sec) 


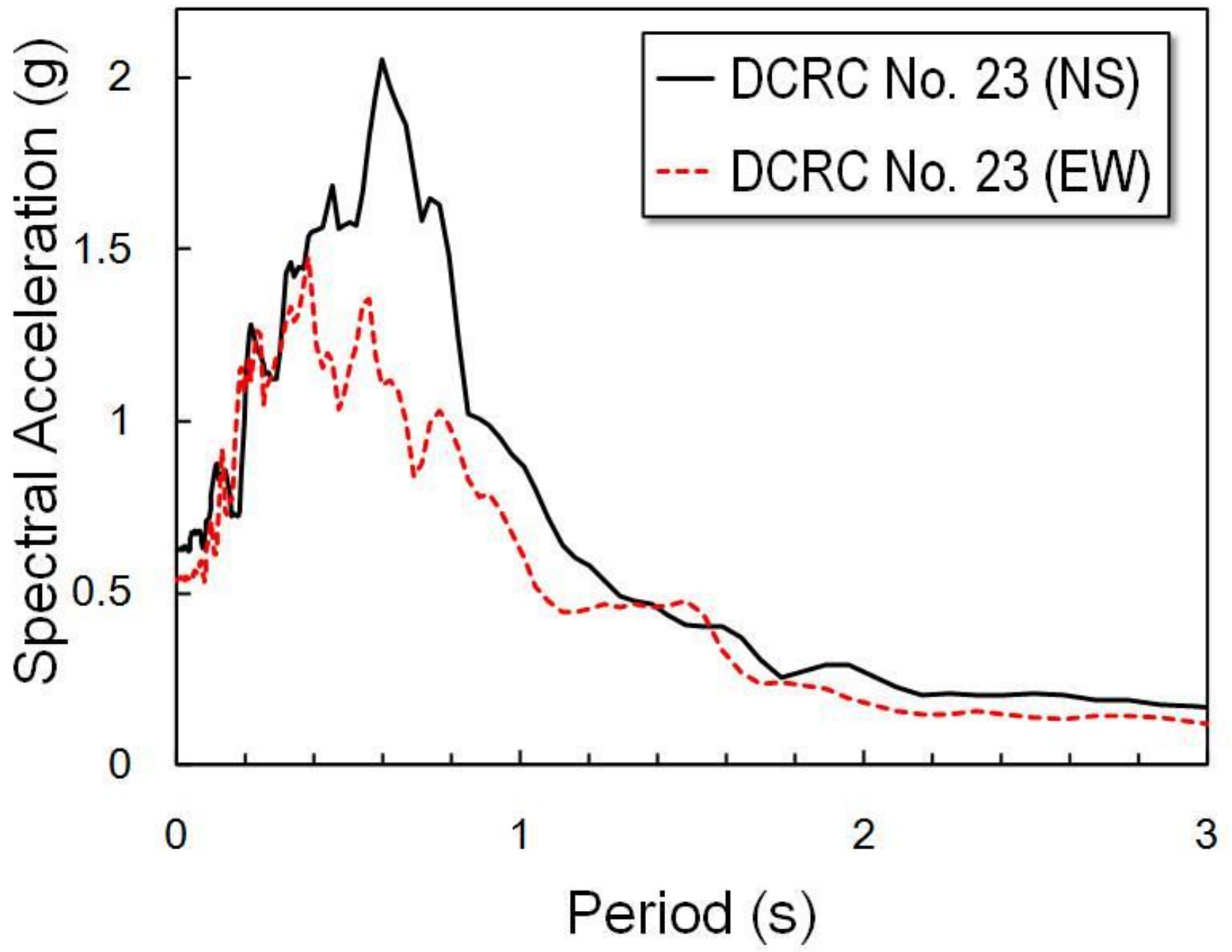


Fig. 5

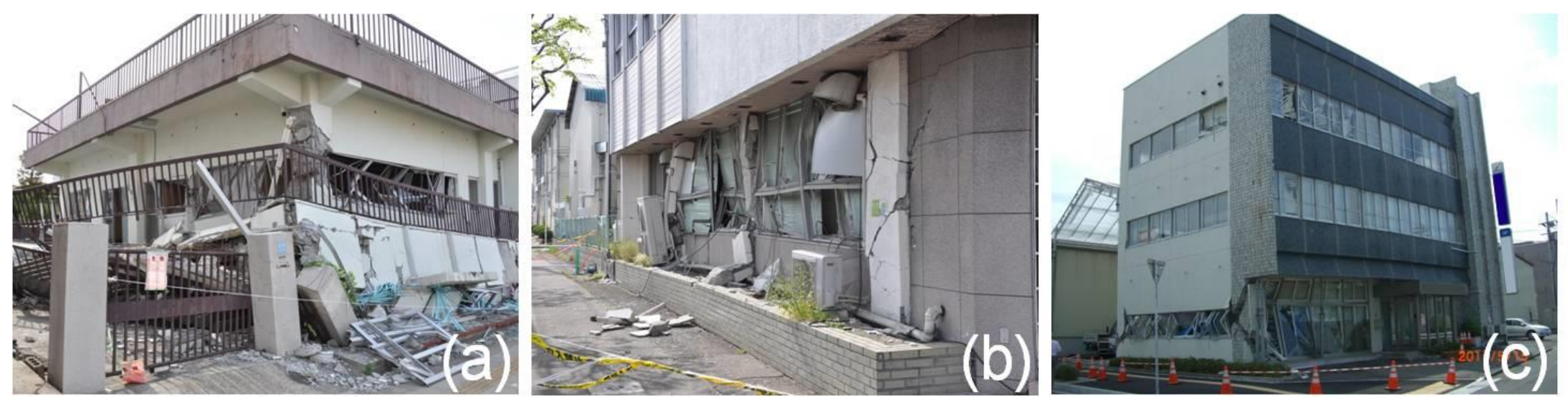


Fig. 6
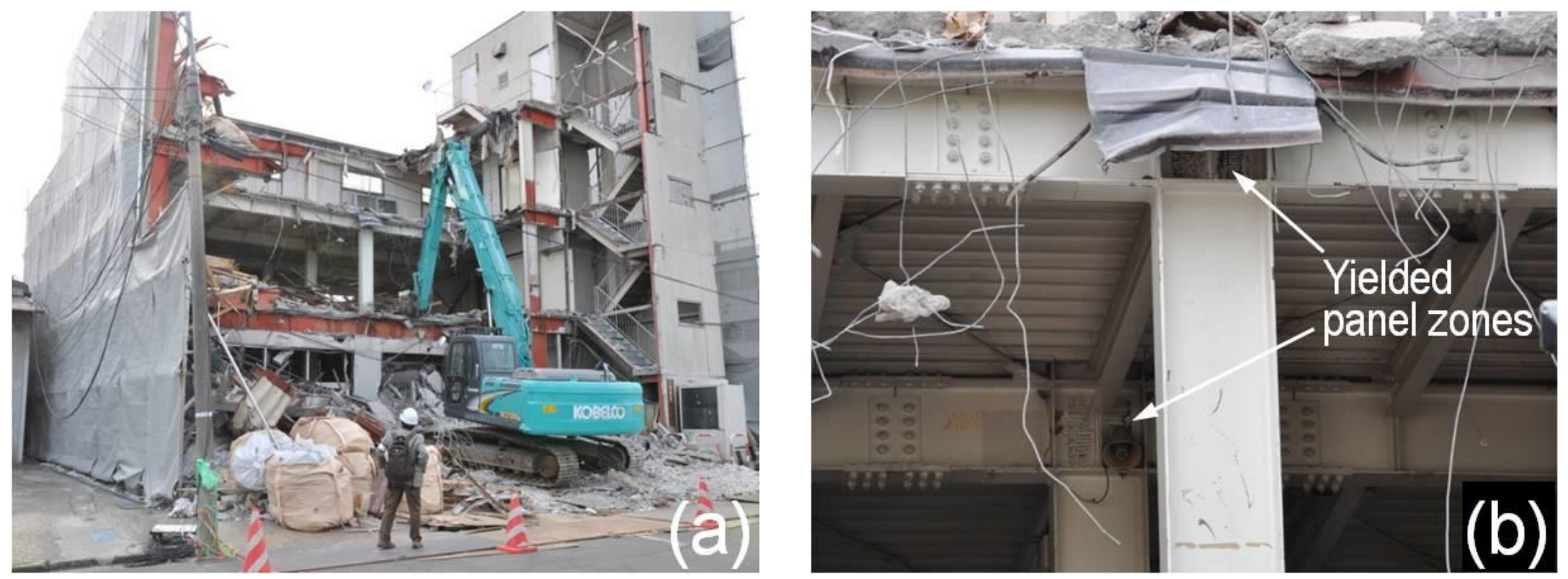
Fig. 7
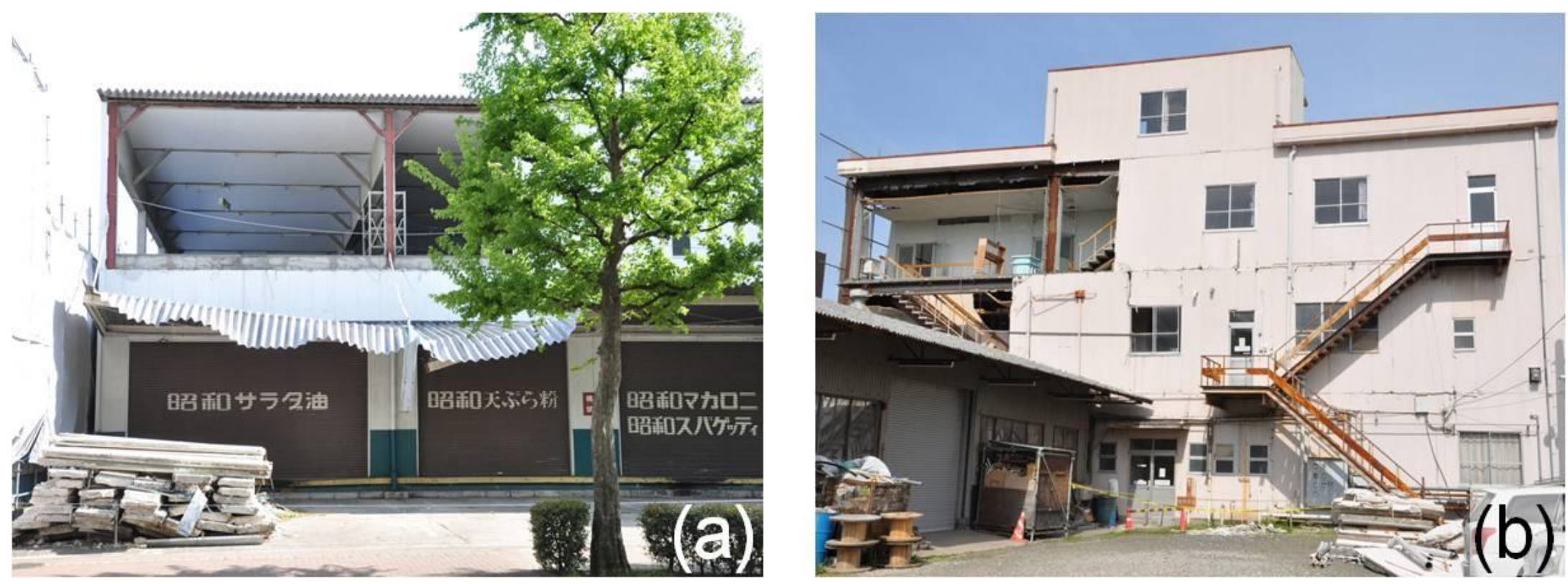
Fig. 8
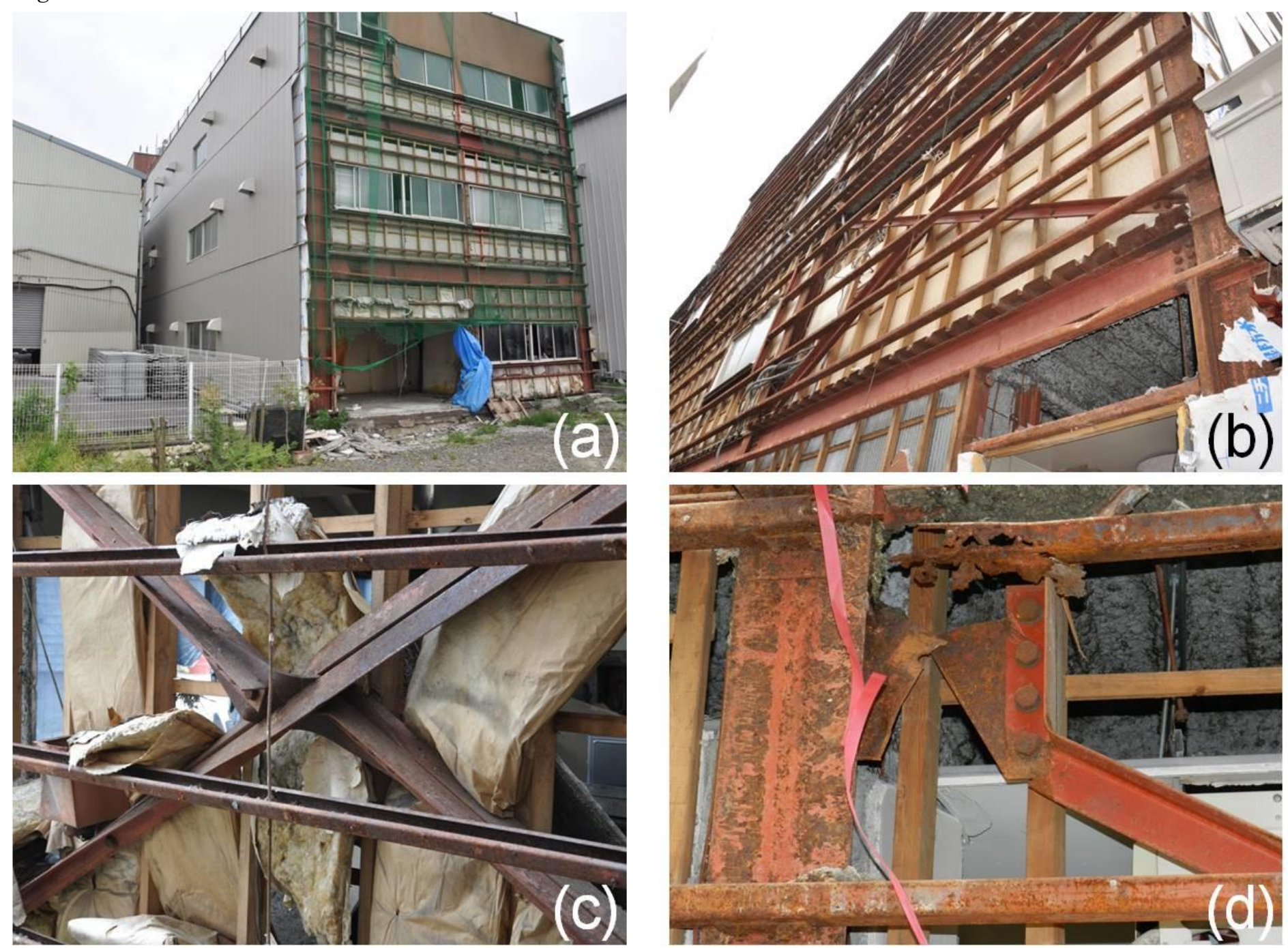
Fig. 9

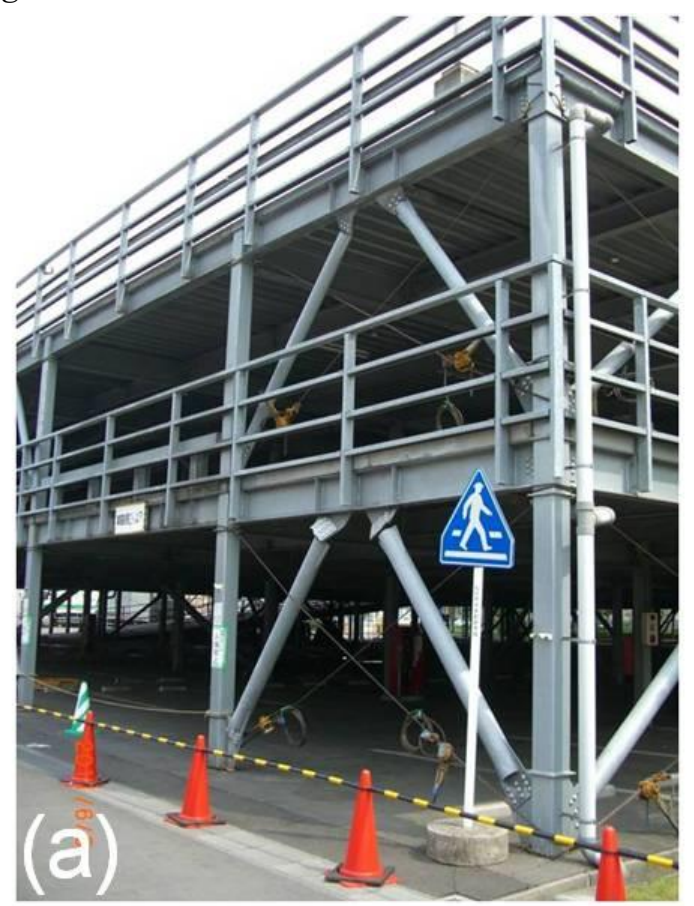

2nd floor beams: $W-346 \times 175 \times 6 \times 9$

Columns:
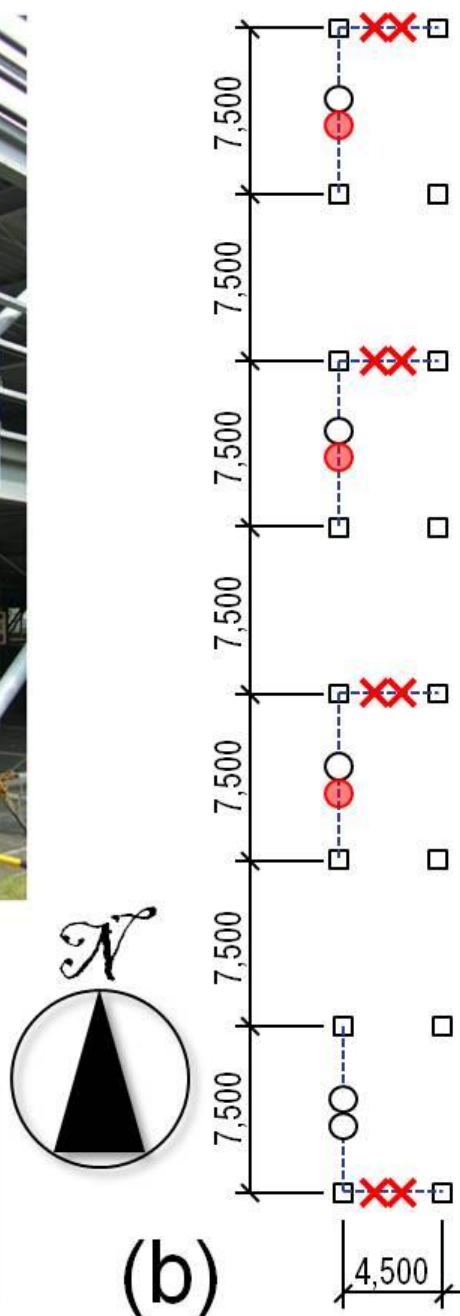

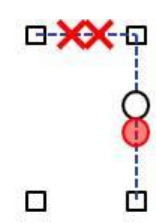

ㅁ

$\square-x \odot \oplus \odot \times \square$

$\square-X \odot \square$

Braces
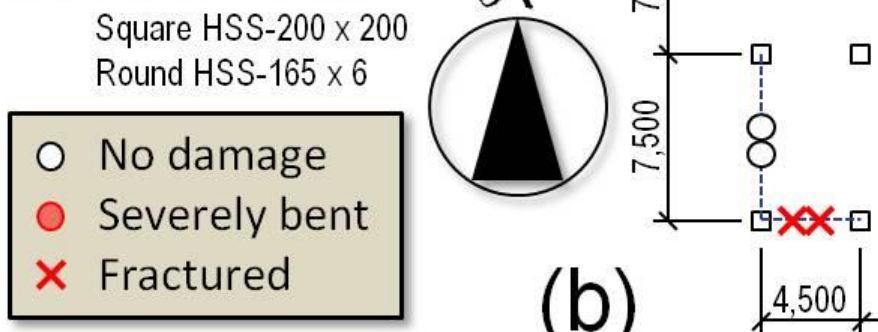

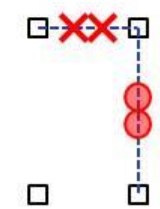

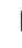

口 口 व
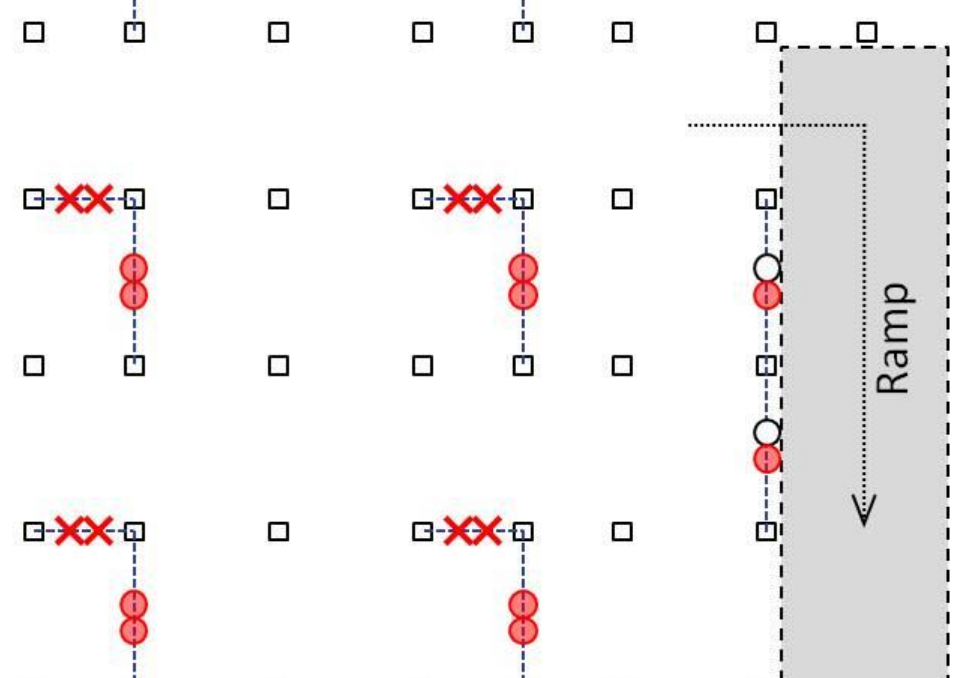

$\square$

$\square-\times \times \square \quad \square$

古:

1
$\square \quad 1$

$\frac{\varrho}{\mathscr{E}}$

口

므스

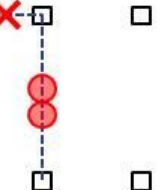

口

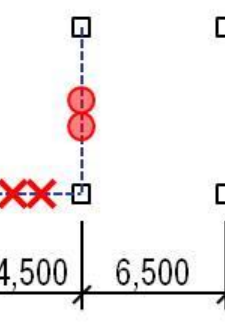

口

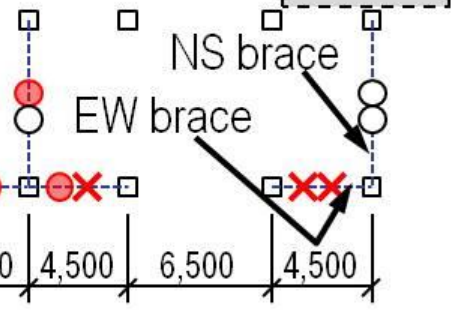

(b)

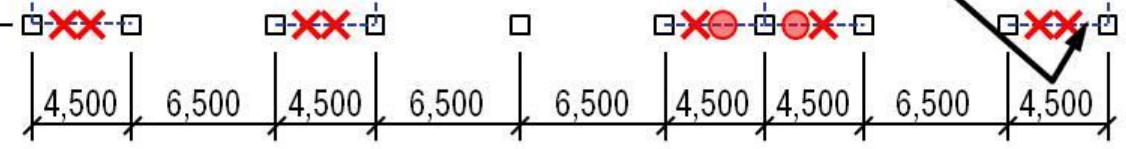


Fig. 10
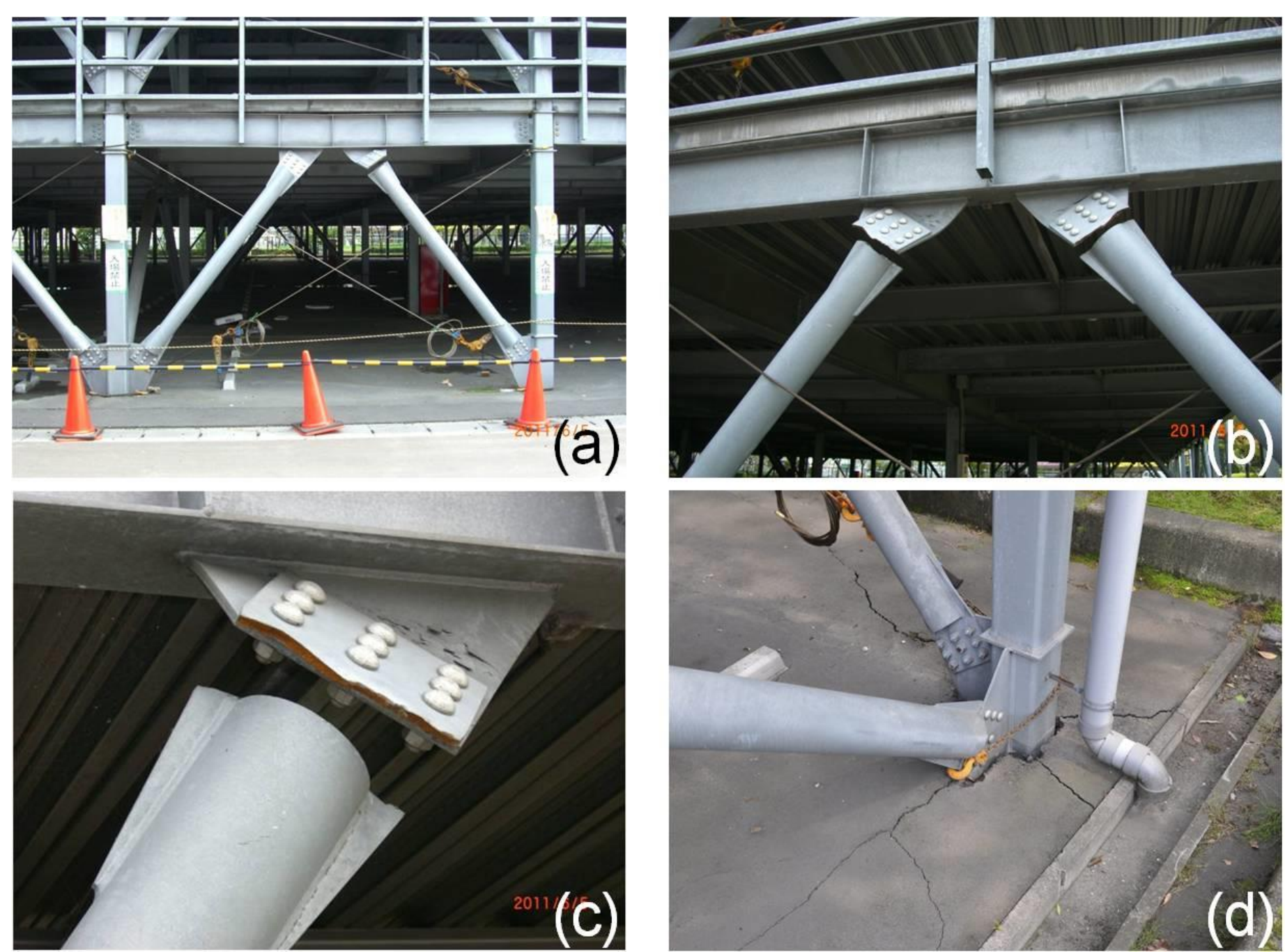
Fig. 11

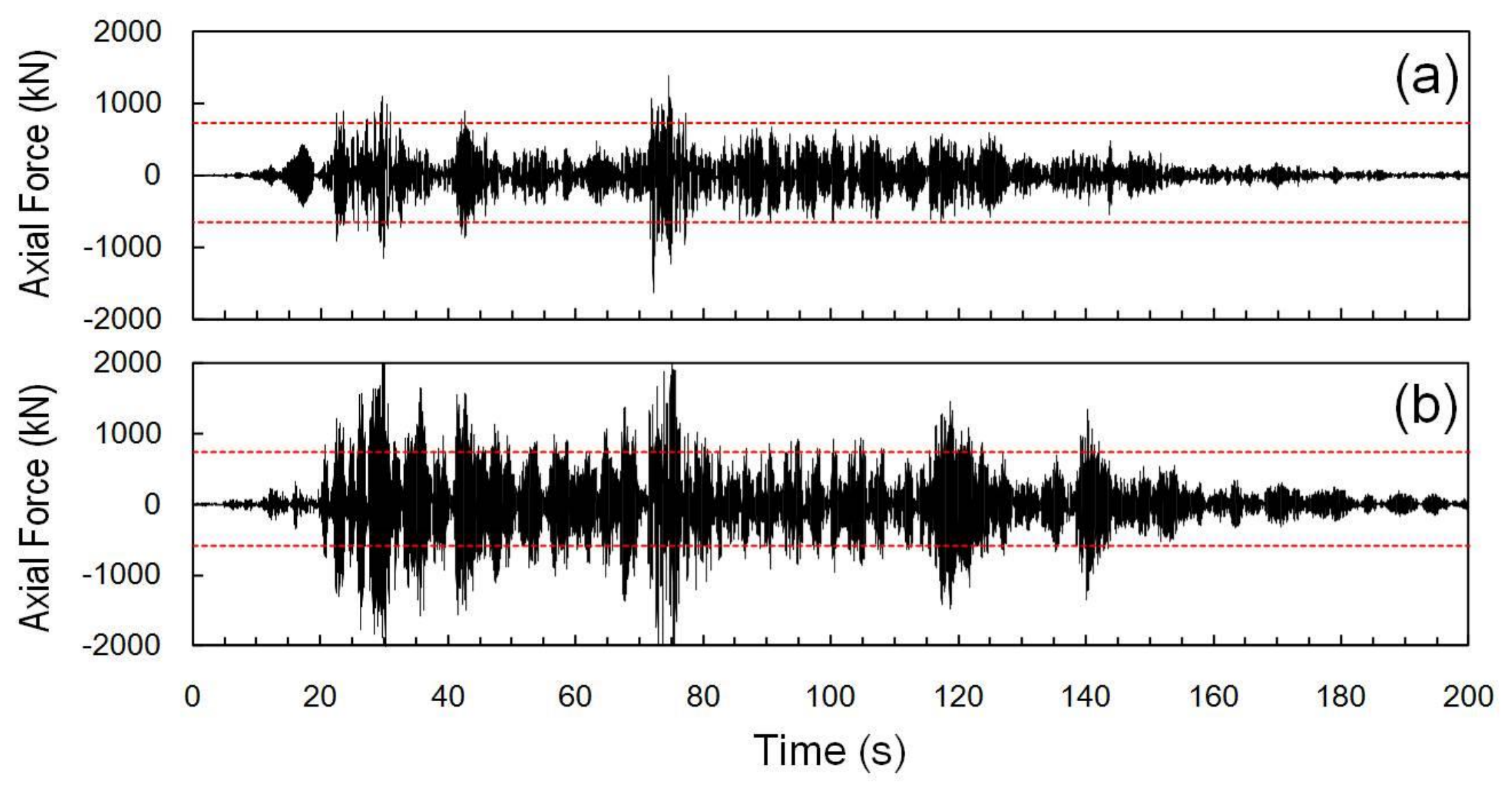


Fig. 12

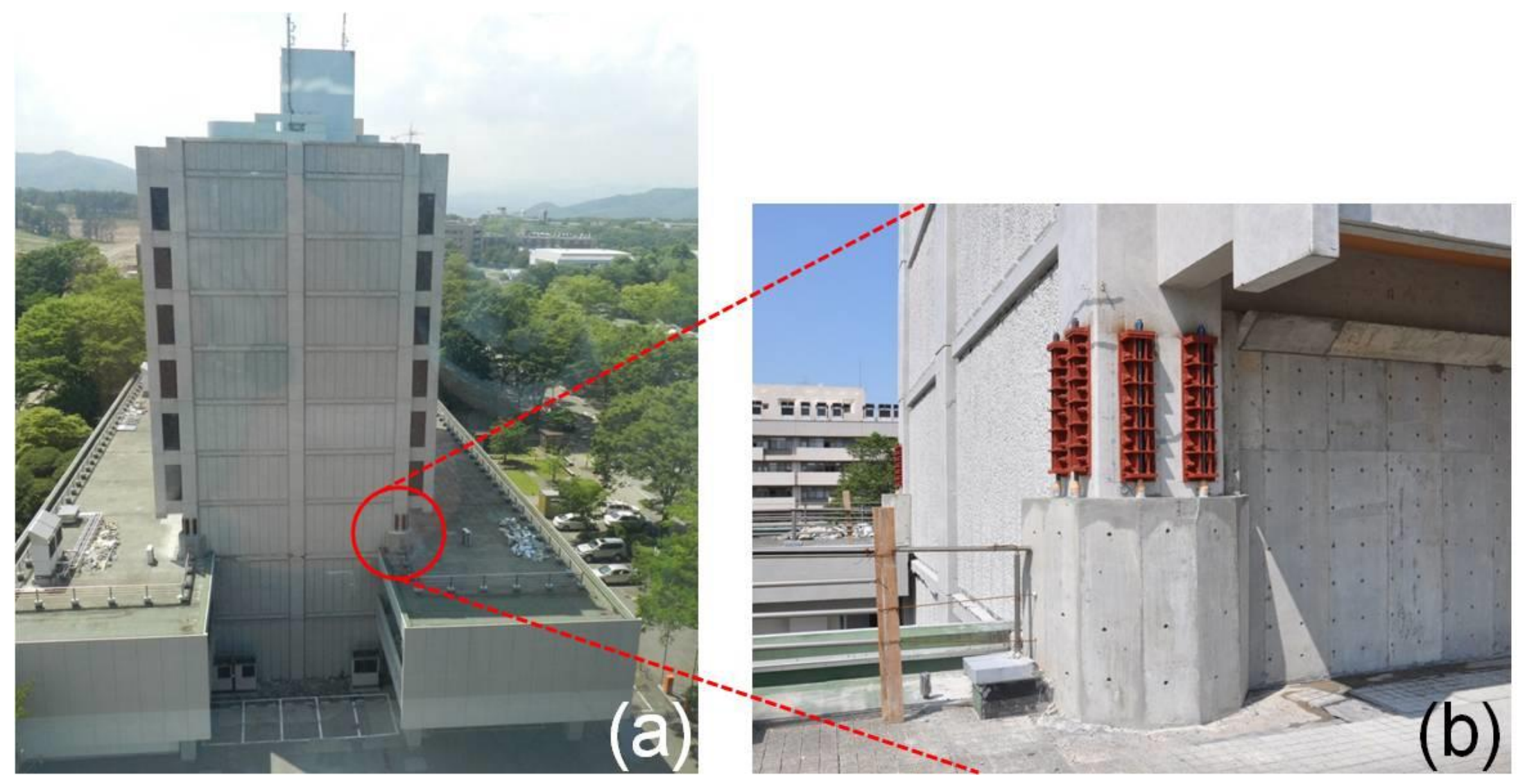


Fig. 13

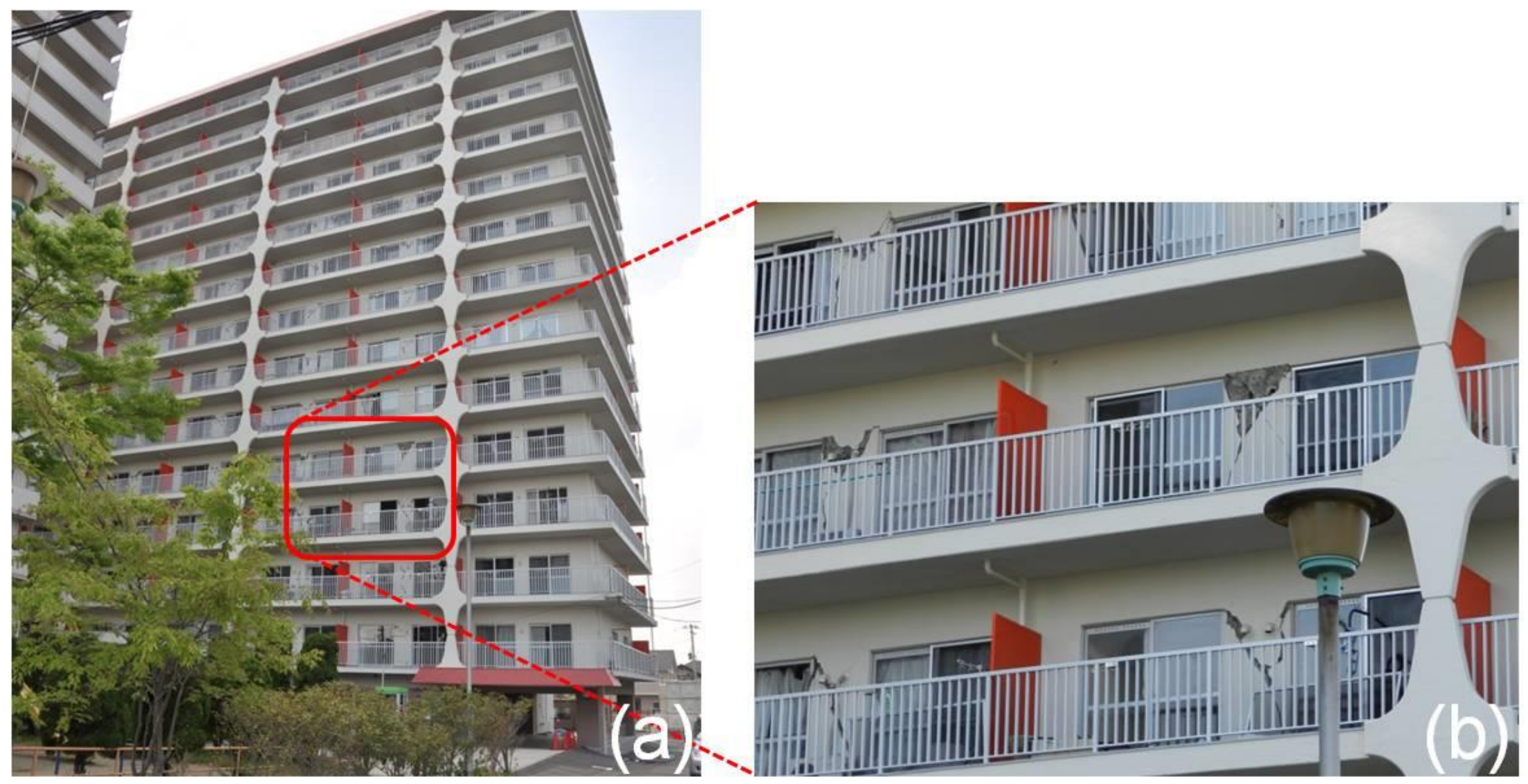


Fig. 14
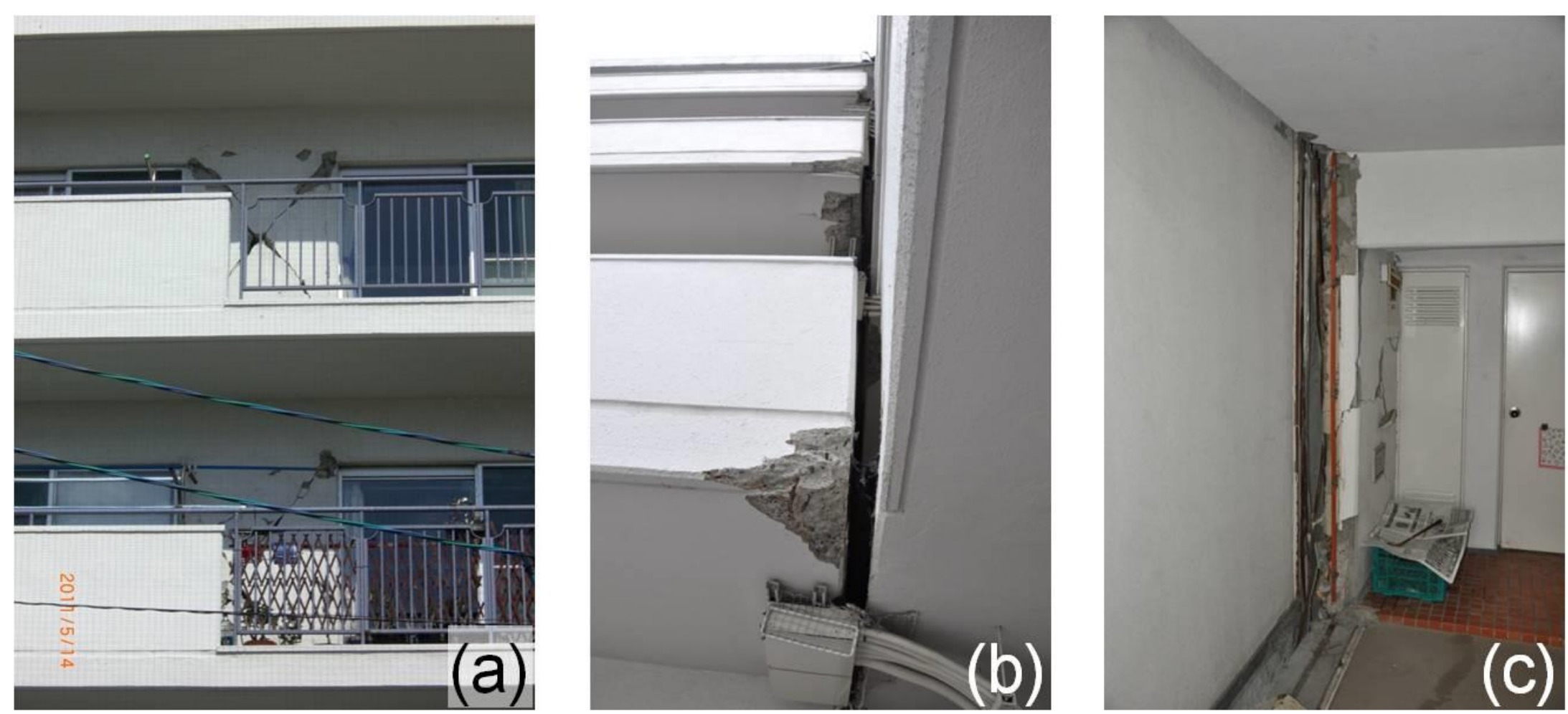
Fig. 15

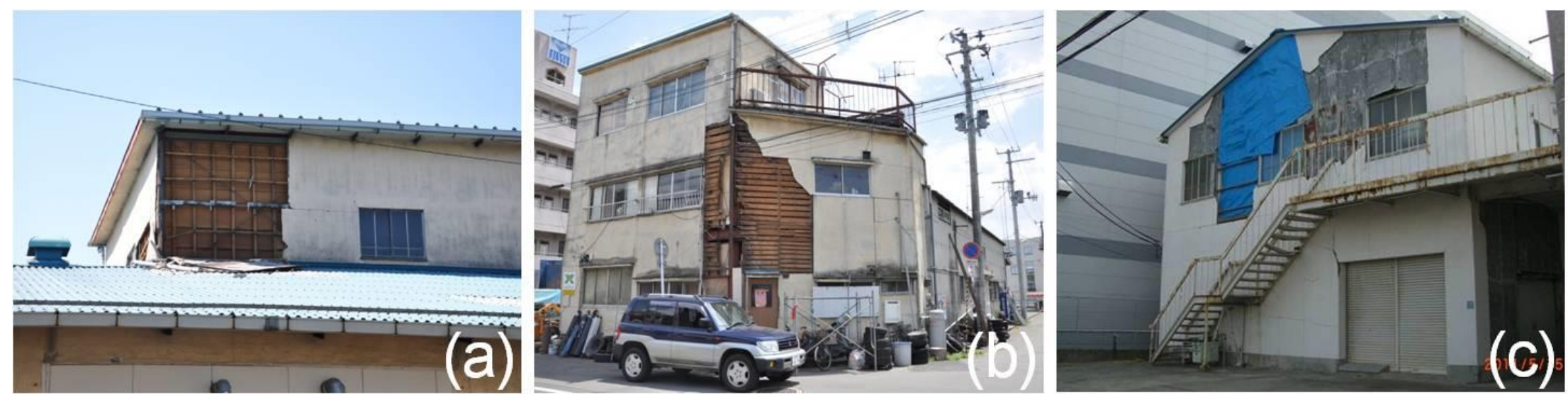


Fig. 16

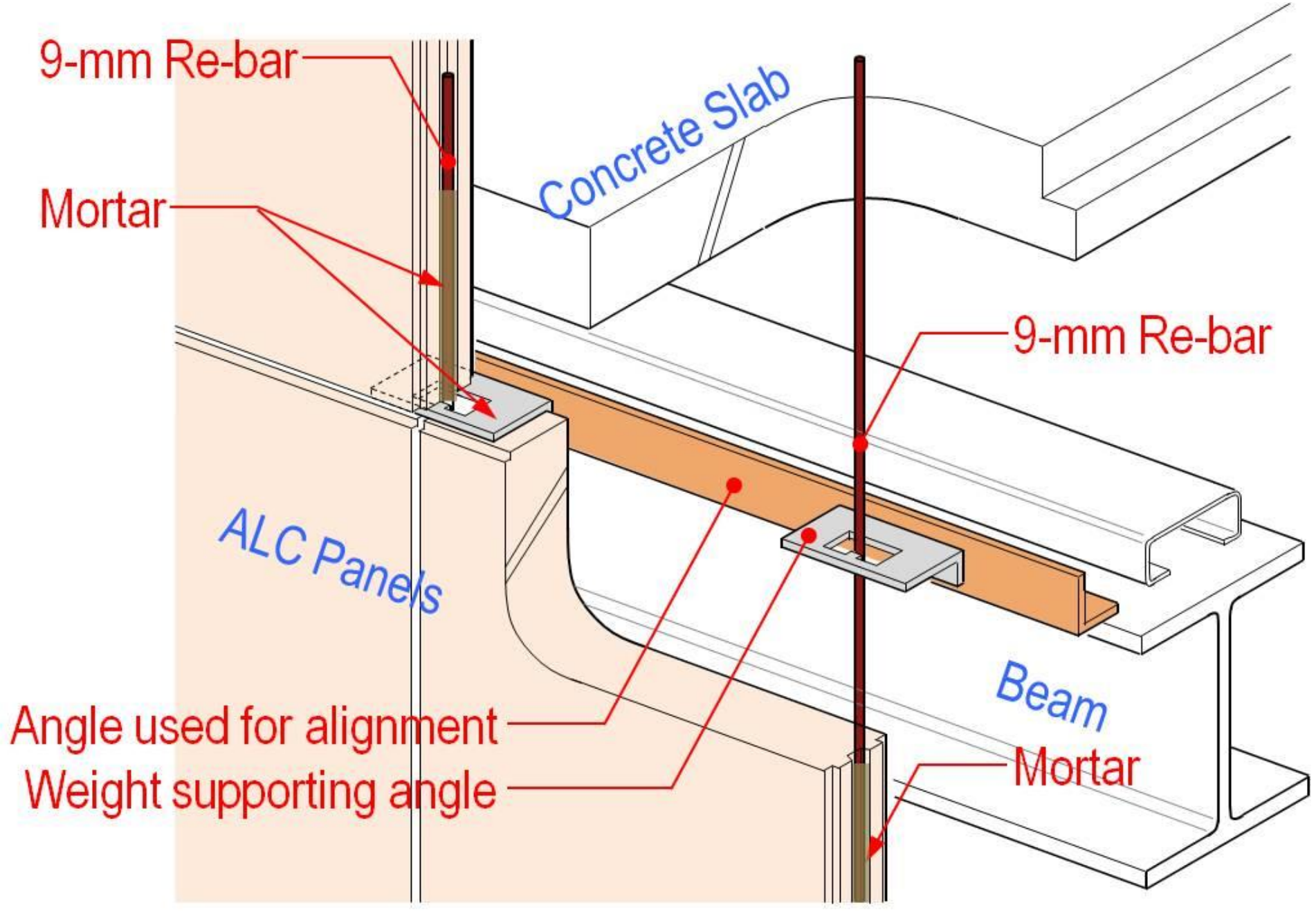




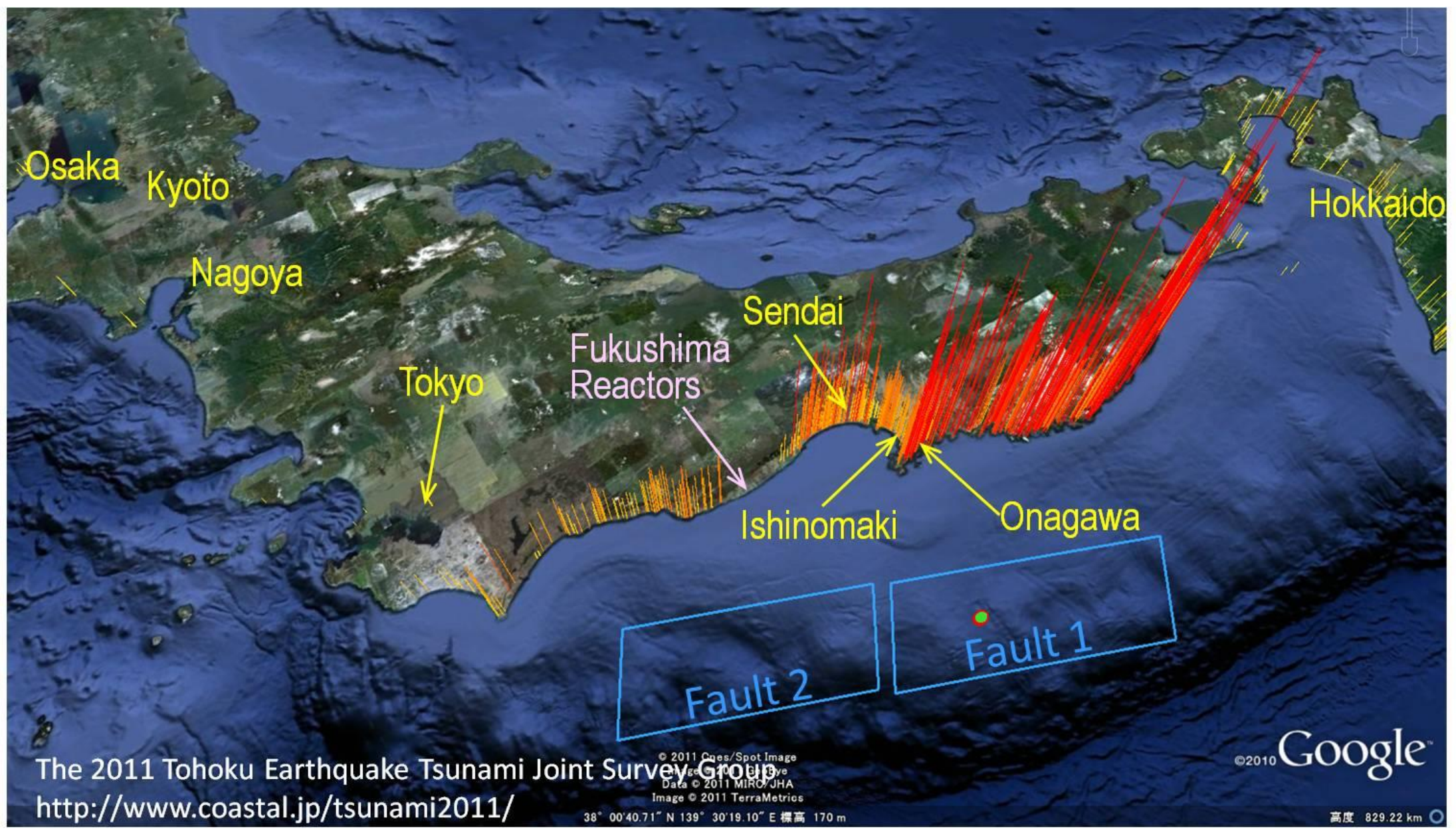


Fig. 18
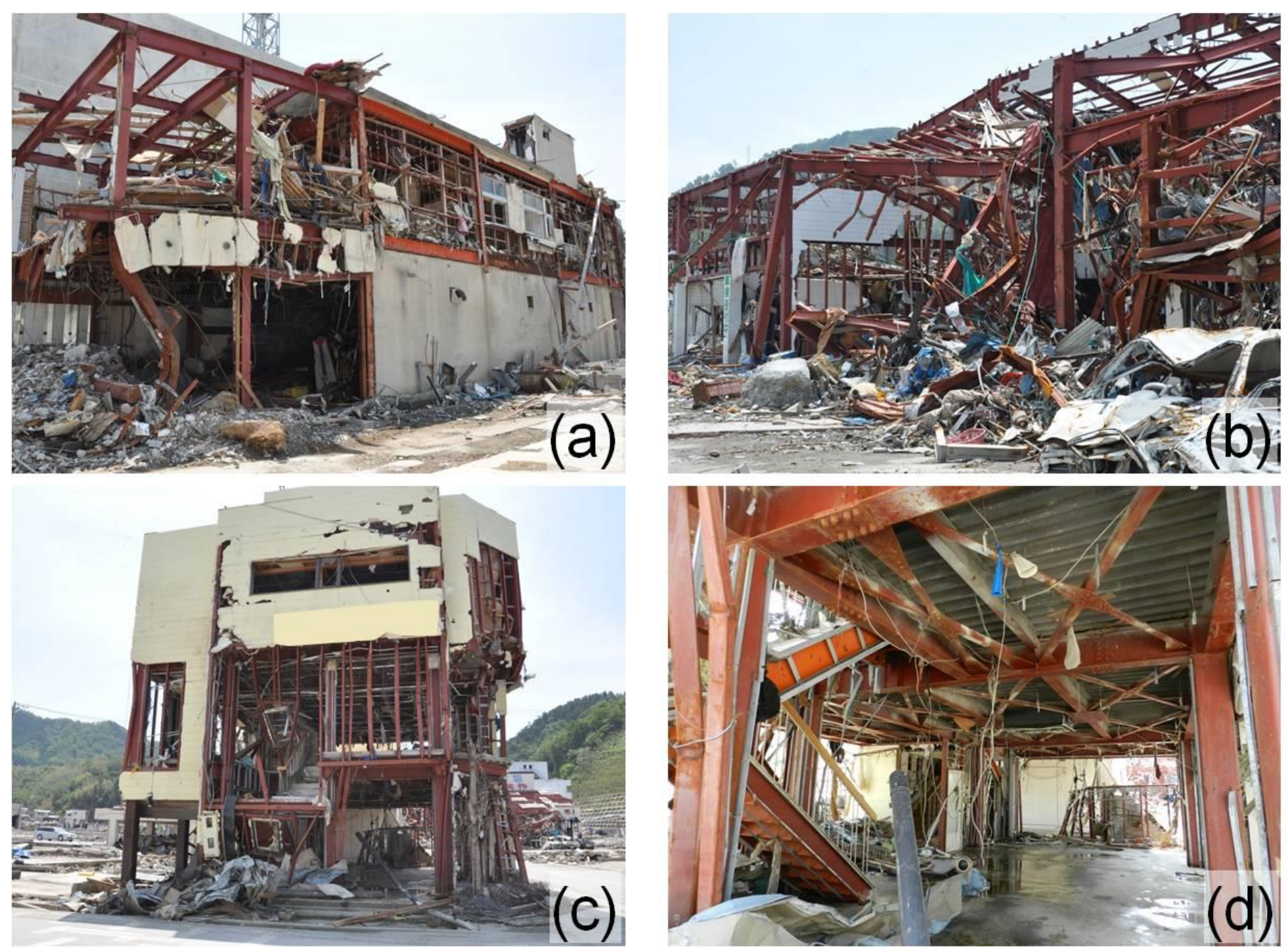
Fig. 19
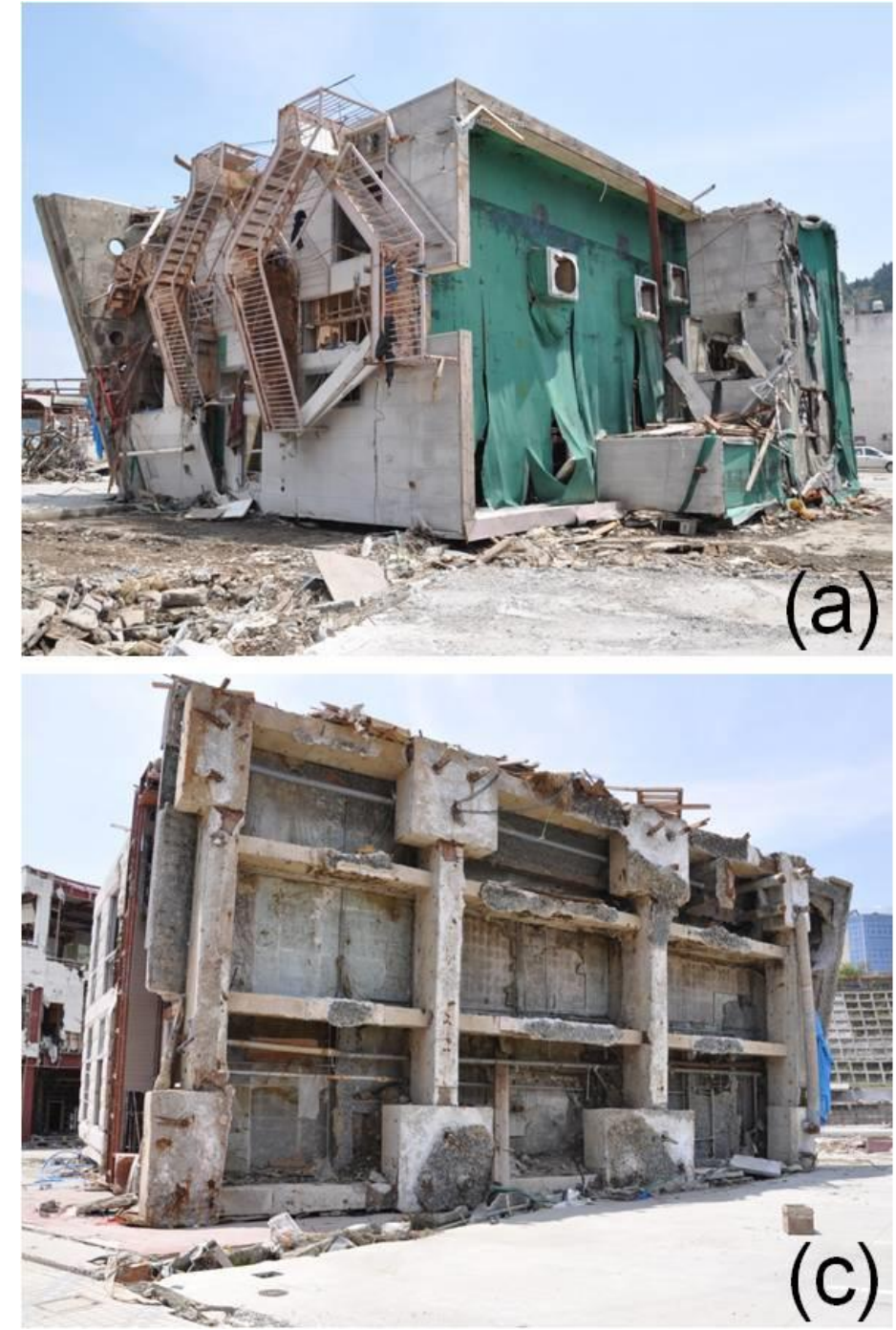

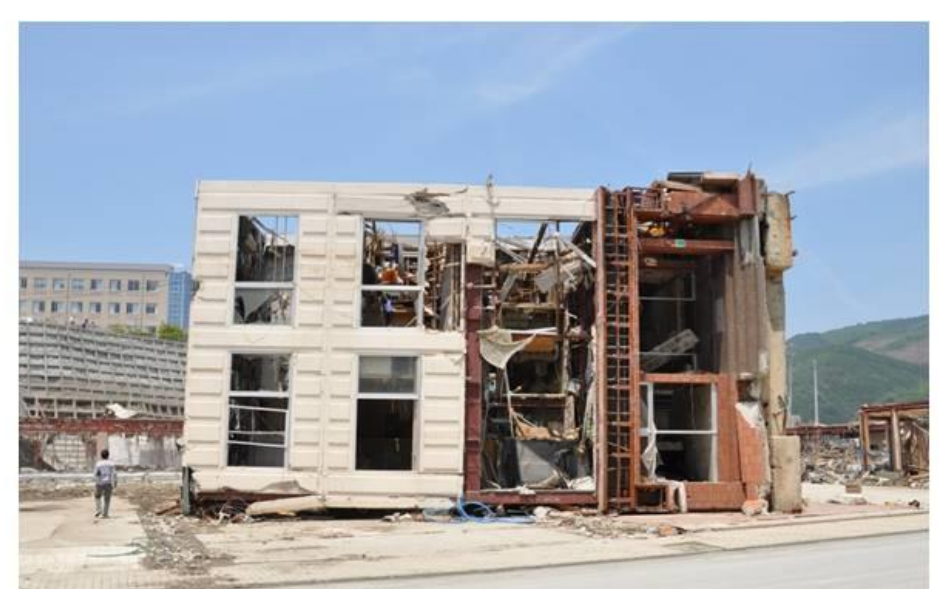

(b)

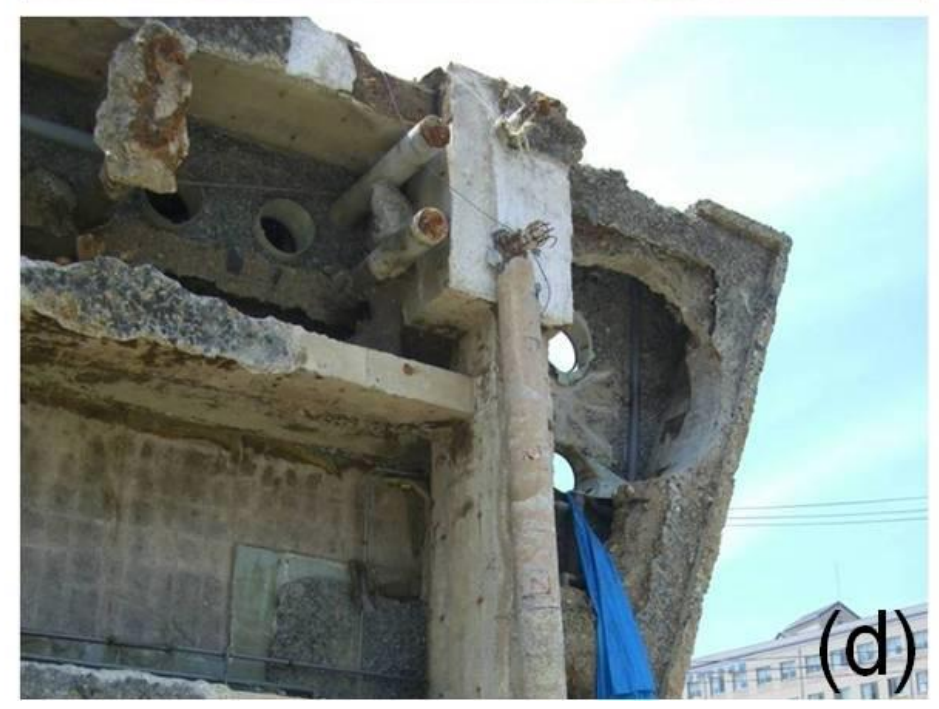


Fig. 20

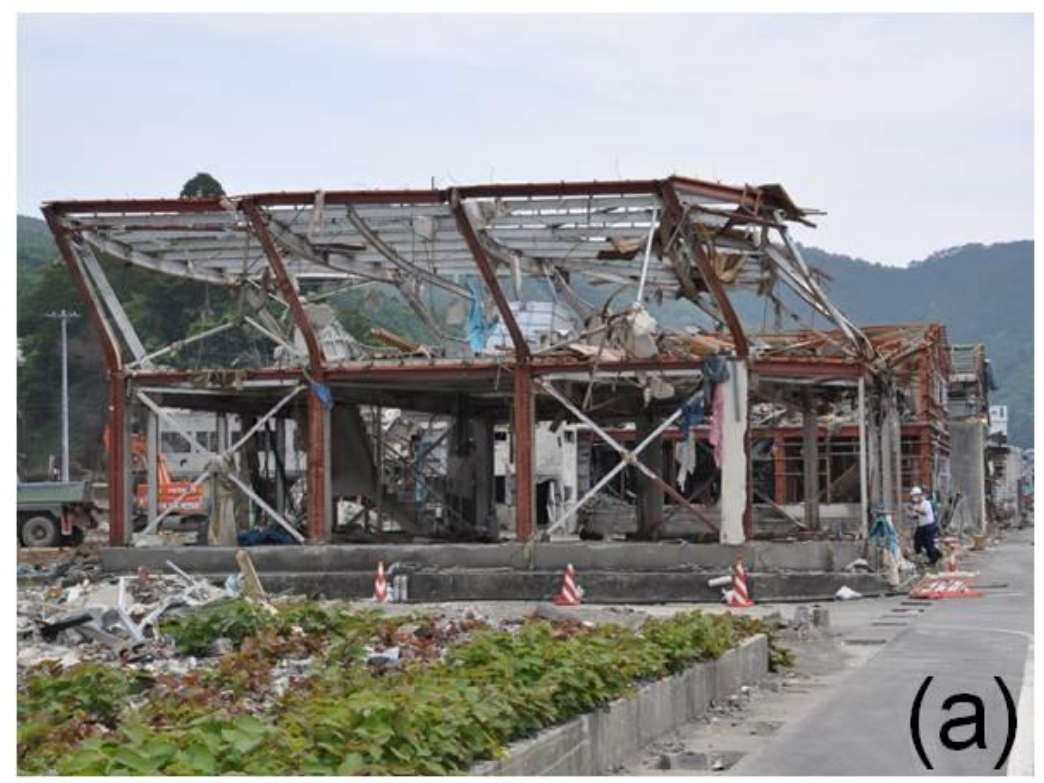

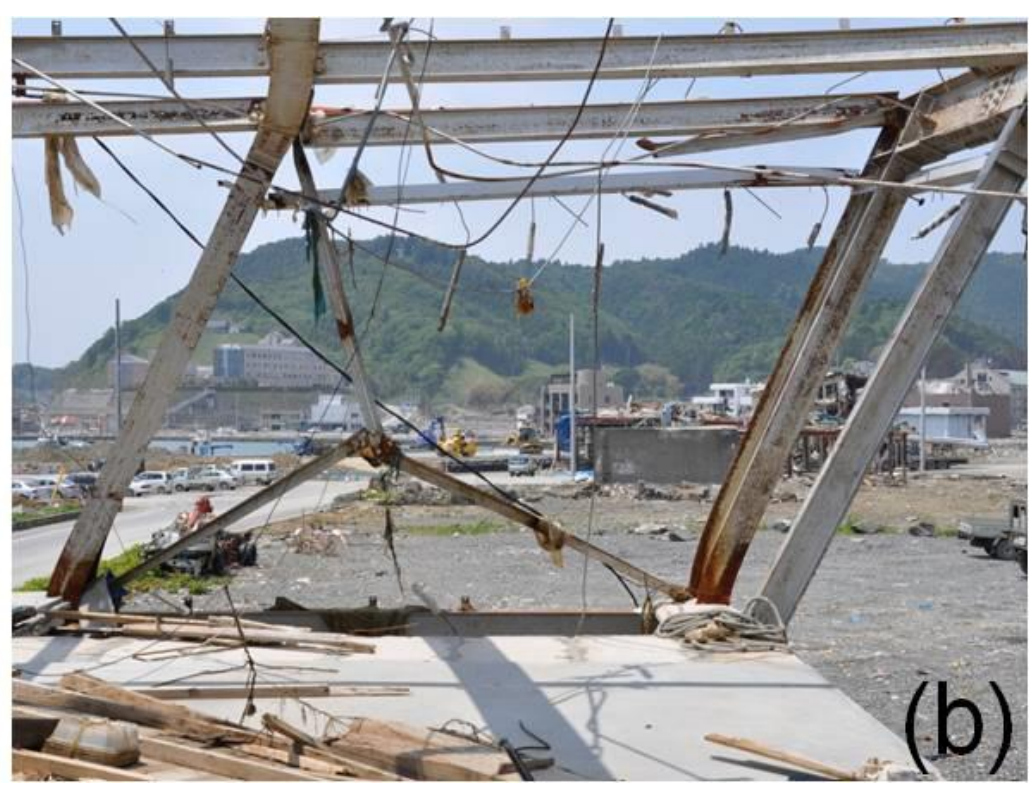


Fig. 21

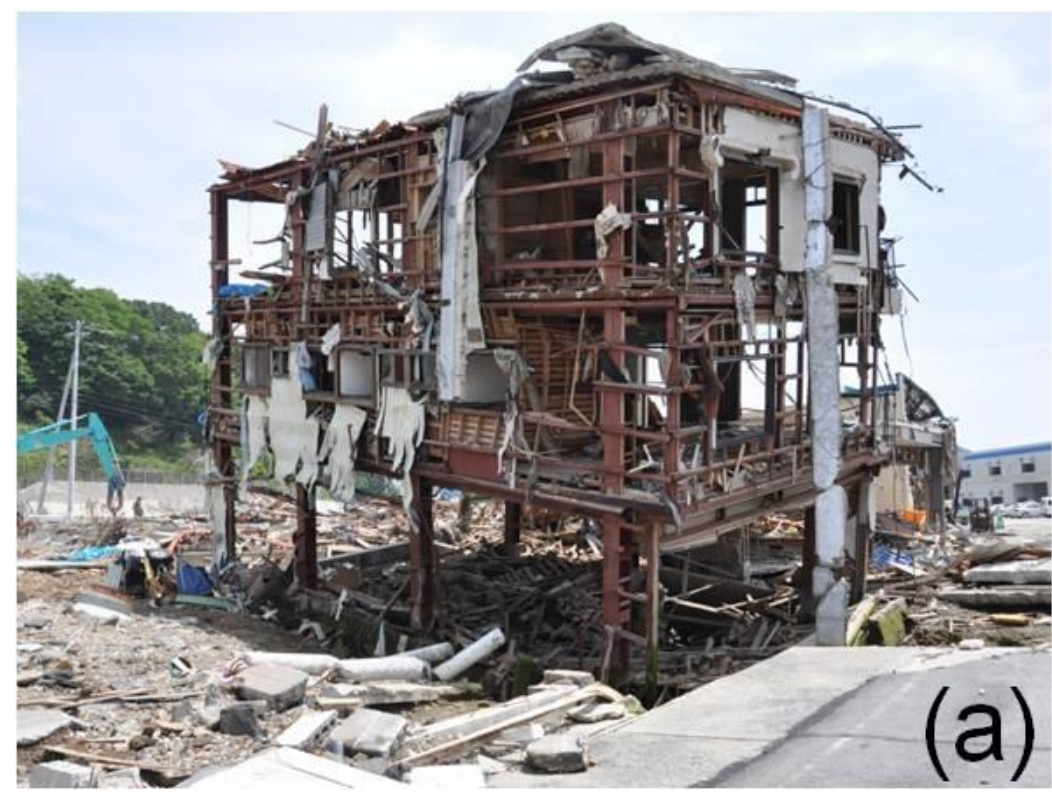

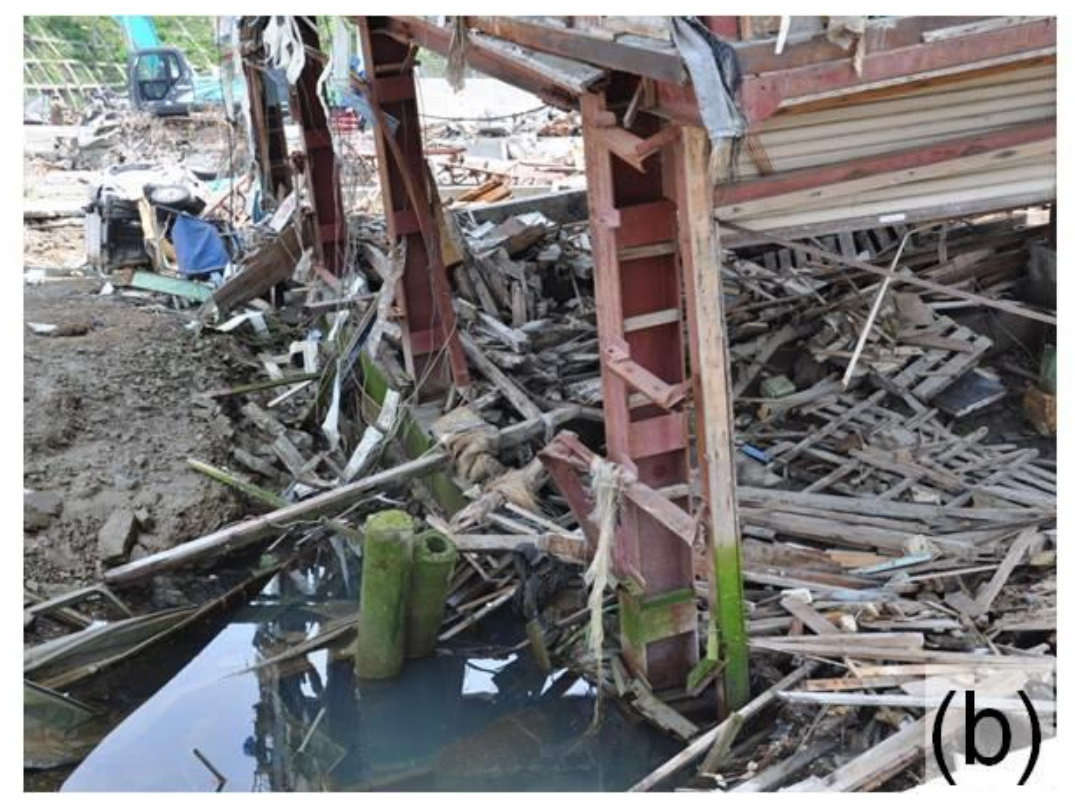


Fig. 22
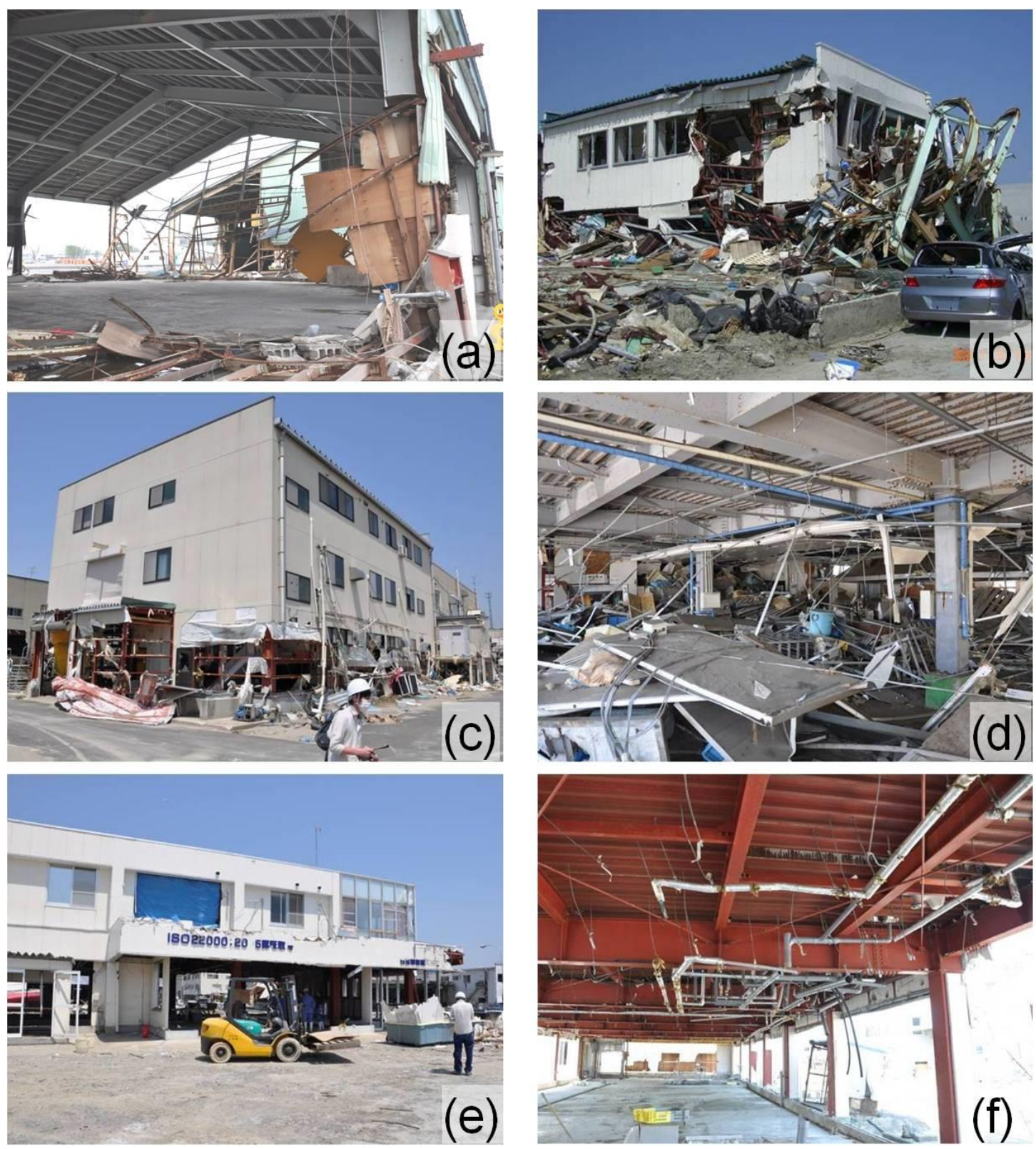
Fig. 23
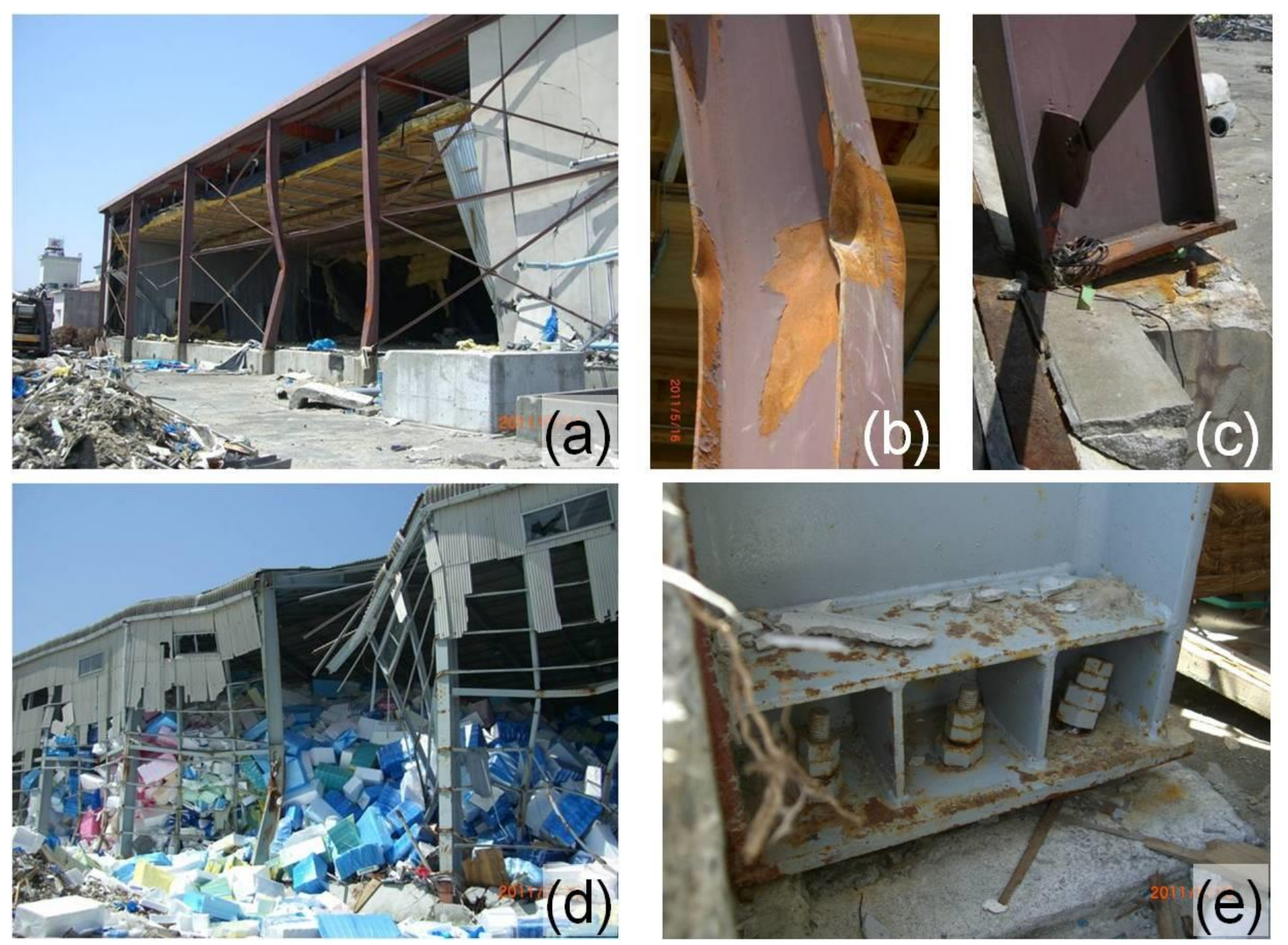

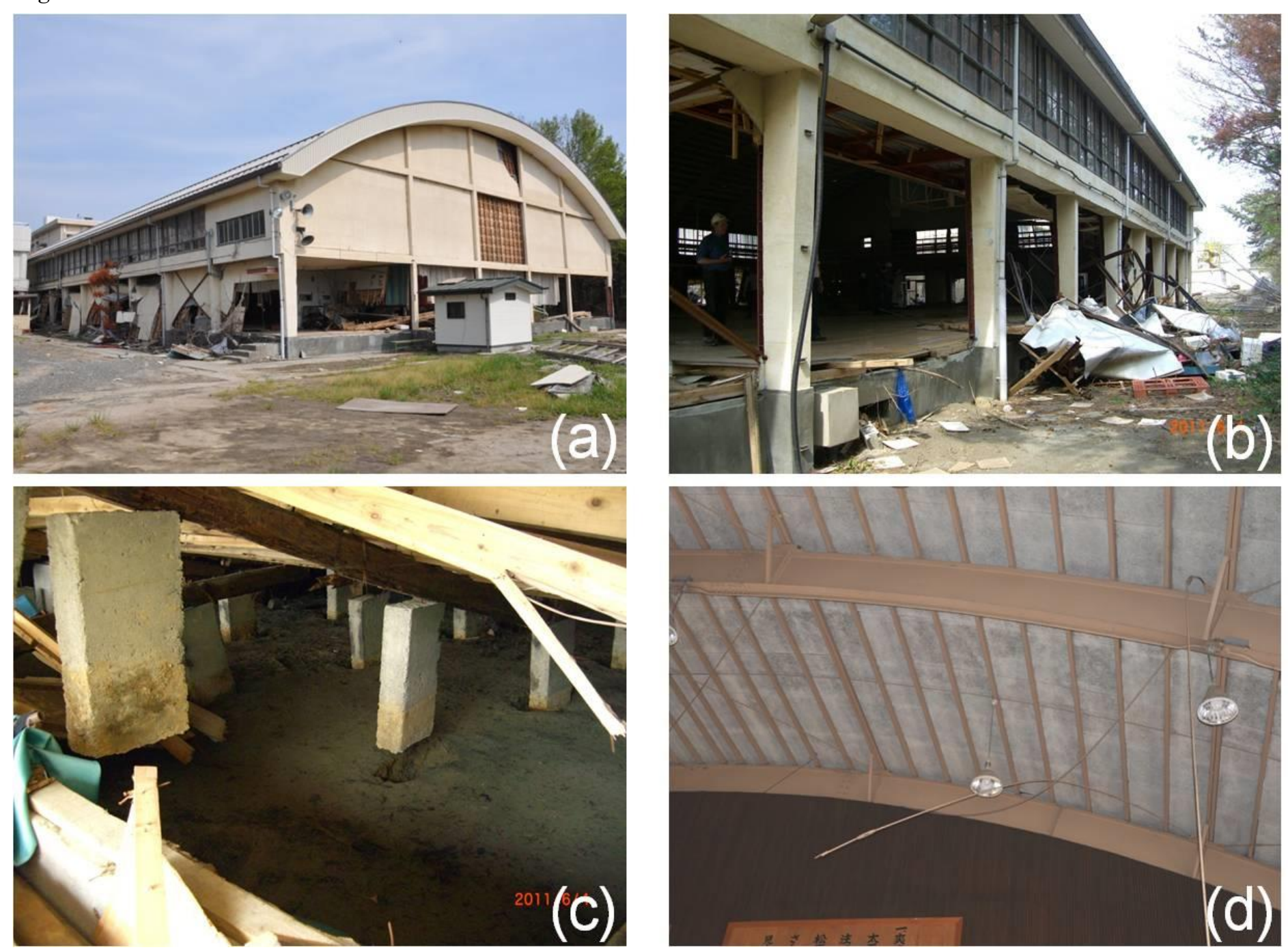
Fig. 25
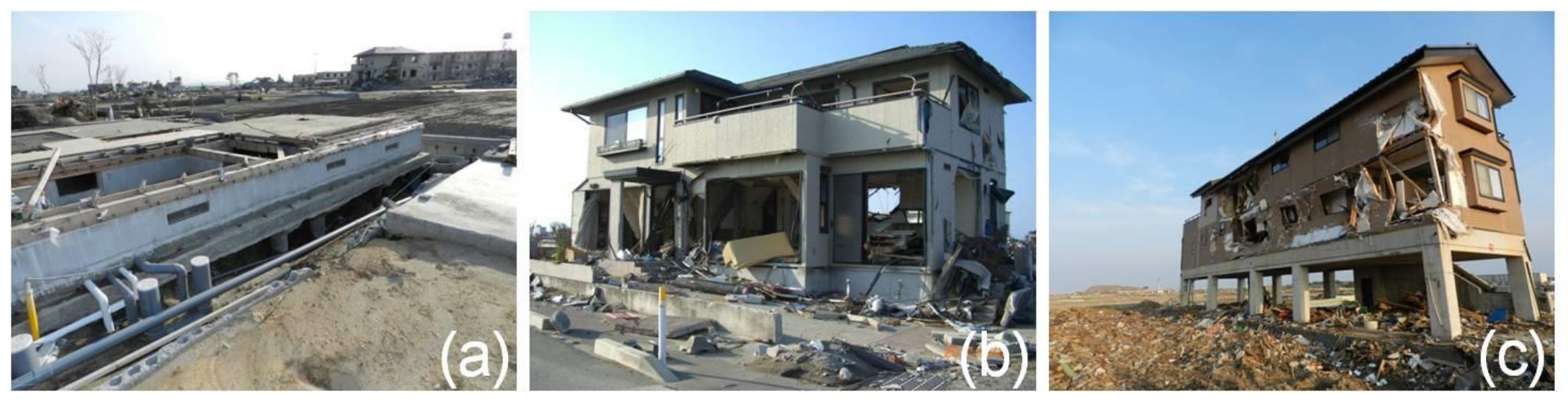
Fig. 26
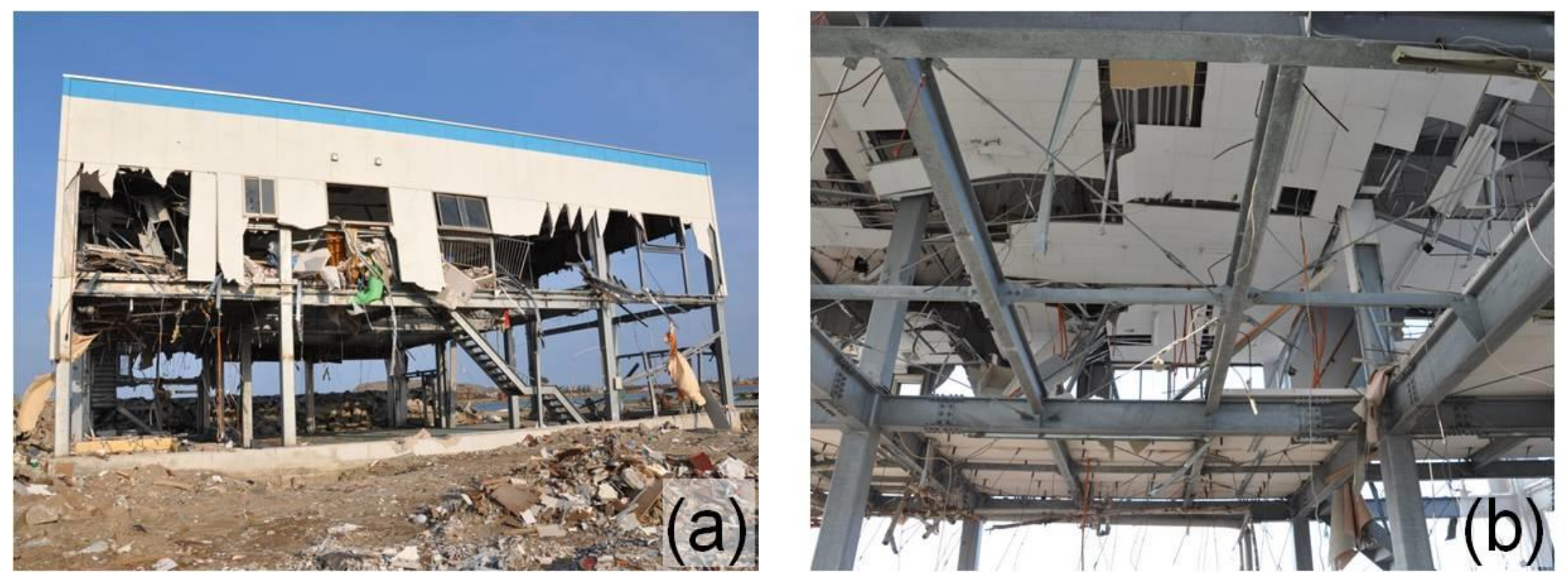
Fig. 27
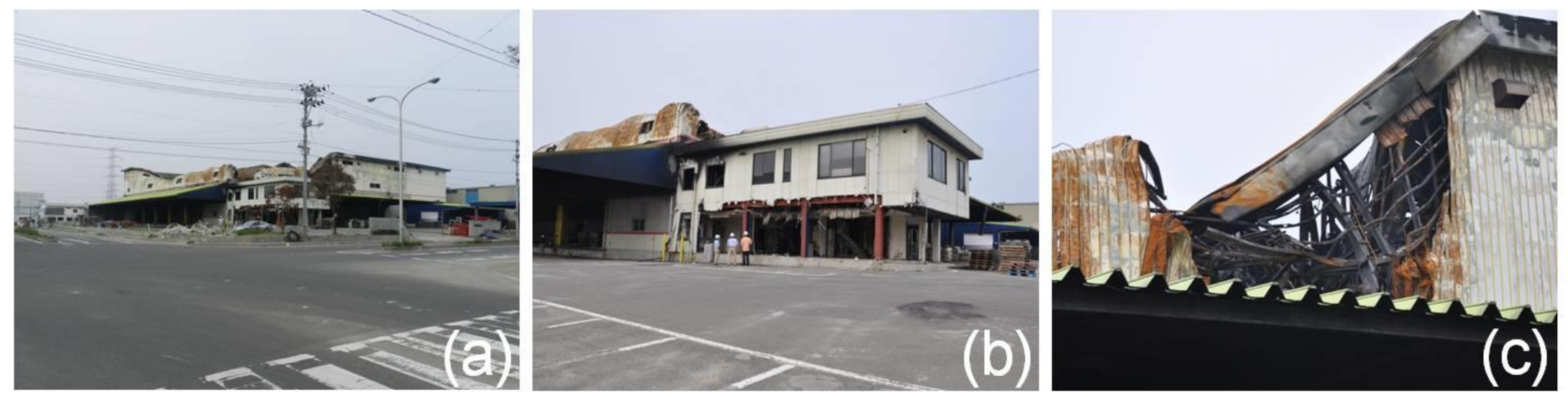